\title{
Reworking of Aggraded Debris Fans by the 1996 Controlled Flood on the Colorado River in Grand Canyon National Park, Arizona
}

By ROBERT H. WEBB, THEODORE S. MELIS, PETER G. GRIFFITHS, AND JOHN G. ELLIOTT

U.S. GEOLOGICAL SURVEY

Open-File Report 97-16

Prepared in cooperation with the BUREAU OF RECLAMATION

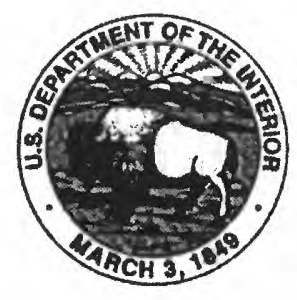




\title{
U.S. DEPARTMENT OF THE INTERIOR BRUCE BABBITT, Secretary
}

\author{
U.S. GEOLOGICAL SURVEY
}

Gordon P. Eaton, Director

The use of trade, product, industry, or firm names is for descriptive purposes only and does not imply endorsement by the U.S. Government.

For additional information write to:

Regional Research Hydrologist U.S. Geological Survey, MS-472 Water Resources Division 345 Middlefield Road Menlo Park, CA 94025
Copies of this report can be purchased from:

U.S. Geological Survey Open-File Reports Section Box 25286, MS 517 Denver Federal Center Denver, CO 80225 
Abstract

Introduction

Purpose and scope.

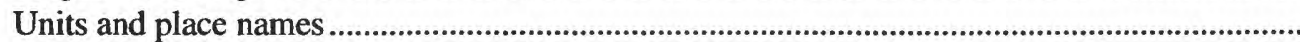

Acknowledgments.

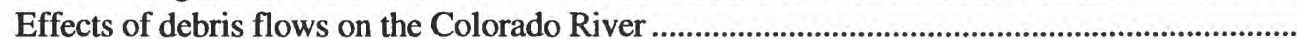

Methods

Hydrographs of the controlled flood

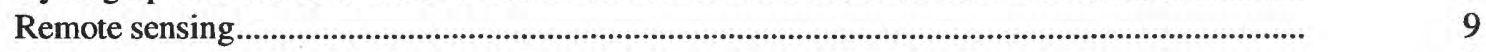

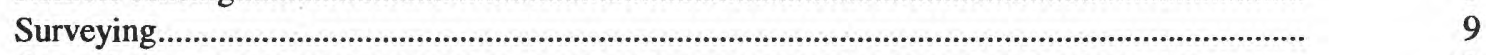

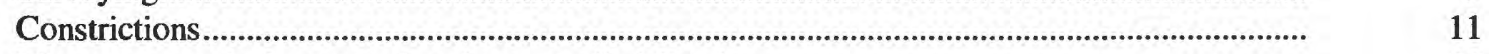

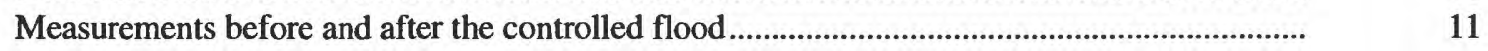

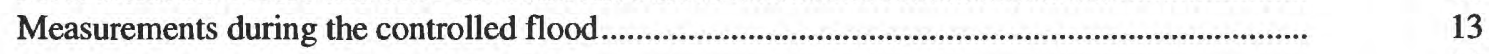

Results

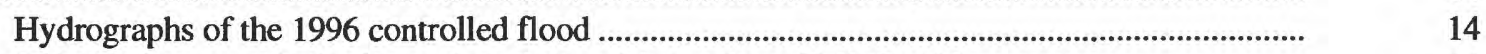

Relation between the hydrograph and reworking at Lava Falls Rapid .....................................

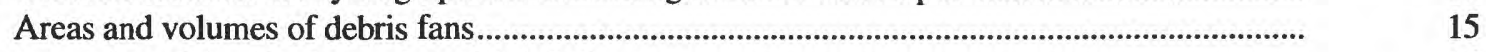

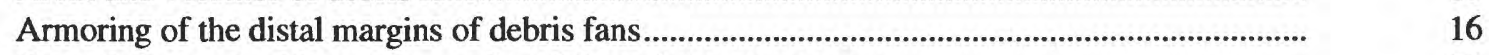

Constriction, velocities, water-surface fall, and stream power .................................................. 21

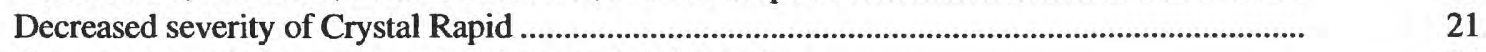

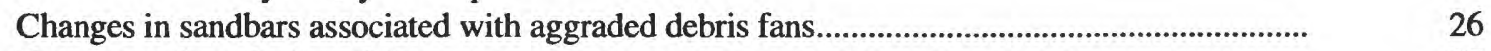

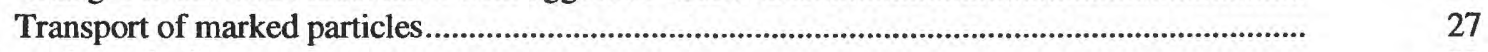

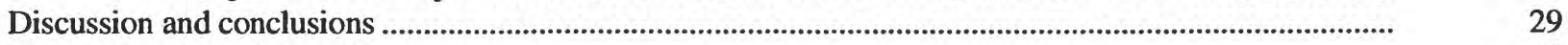

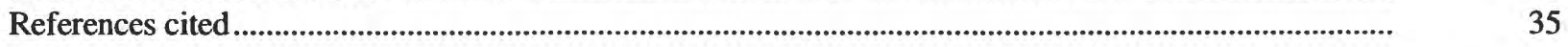

\section{FIGURES}

1. Map of the Colorado River in Grand Canyon showing the locations of monitored debris fans .....

2. Graph of the annual flood series for the Colorado River near Grand Canyon, Arizona ..................

3. Schematic diagram showing reworking of debris fans by the Colorado River in Grand Canyon..

4. Graph of particle-size distributions showing armoring of a debris fan.

5. Hydrographs of the Colorado River showing discharges of the 1996 controlled flood in Grand Canyon at three gaging stations.

6. Hydrographs of selected Colorado River floods and the 1996 controlled flood..

7. Aerial photographs of Lava Falls Rapid before and after the 1996 controlled flood..

8. Hydrographs showing the relation between stage, discharge, and reworking at Lava Falls Rapid during the 1996 controlled flood.

9. Replicate photographs of the debris fan at 62.5 Mile .

11. Graph of particle-size distributions showing pristine debris flows, reworking by combined powerplant releases and tributary inflows, reworking by the 1996 controlled flood, and armoring that resulted from pre-dam floods in Grand Canyon

12. Graphs of particle-size distributions and lithologies at Lava Falls Rapid before and after the 1996 controlled flood

13. Graphs of water-surface profiles through selected rapids reworked by the 1996 controlled flood

14. Aerial photographs of Crystal Rapid before and after the 1996 controlled flood. before and after the 1996 controlled flood.

16. Graphs showing the presence of marked particles placed on the Palisades Creek debris fan 
17. Map showing the depositional sites of radio-tagged cobbles and boulders downstream from Lava Falls Rapid after the 1996 controlled flood

18. Graph showing the relation between streampower, date of debris flows, and changes in area and volume of aggraded debris fans reworked by the 1996 controlled flood in Grand Canyon.

19. Graph of changes in percent constrictions of debris fans in Grand Canyon reworked by the 1996 controlled flood.

\section{TABLES}

1. Characteristics of debris fans aggraded after 1983 in Grand Canyon ...........................................

2. Changes in the areas of debris fans reworked by the 1996 controlled flood in Grand Canyon ...... $\quad 16$

3. Changes in the volumes of debris fans reworked by the 1996 controlled flood in Grand Canyon.

4. Changes in particle-size distributions of debris fans reworked by the 1996 controlled flood in Grand Canyon

5. Changes in the width of the reworked zone of debris fans reworked and area of debris fan inundated by the 1996 controlled flood in Grand Canyon

6. Changes in the constrictions of the Colorado River by debris fans reworked by the $\mathbf{1 9 9 6}$ controlled flood in Grand Canyon

7. Velocities measured in rapids and riffles during the 1996 controlled flood in Grand Canyon........

8. Changes in water-surface profiles and stream power around selected debris fans reworked by the 1996 controlled flood in Grand Canyon

9. Changes in the areas of sandbars associated with debris fans reworked by the 1996 controlled flood in Grand Canyon

10. Movement of marked boulders from five debris fans during the 1996 controlleed flood

11. Characteristics of radio-tagged boulders at Lava Falls Rapid transported during the $\mathbf{1 9 9 6}$ controlled flood in Grand Canyon

\section{CONVERSION FACTORS}

For readers who prefer to use inch-pound units, conversion factors for the terms in this report are listed below:

\begin{tabular}{lcl}
\hline Multiply & By & \multicolumn{1}{c}{ To obtain } \\
\hline millimeter $(\mathrm{mm})$ & 0.03937 & inch (in.) \\
meter $(\mathrm{m})$ & 3.2818 & foot $(\mathrm{ft})$ \\
square meter $\left(\mathrm{m}^{2}\right)$ & 10.76 & square foot $\left(\mathrm{ft}^{2}\right)$ \\
cubic meter $\left(\mathrm{m}^{3}\right)$ & 35.31 & cubic foot $\left(\mathrm{ft}^{3}\right)$ \\
kilometer $(\mathrm{km})$ & 0.6214 & mile $(\mathrm{mi})$ \\
cubic meter per second $\left(\mathrm{m}^{3} / \mathrm{s}\right)$ & 35.31 & cubic foot per second $\left(\mathrm{ft}^{3} / \mathrm{s}\right)$ \\
gram $(\mathrm{g})$ & 0.03527 & ounce avoirdupois $(\mathrm{oz}$ avdp) \\
kilogram $(\mathrm{kg})$ & 2.205 & pound avoirdupois $(\mathrm{lb}$ avdp) \\
megagram $(\mathrm{Mg})$ & 1.102 & tons, short $(2,000$ pounds) \\
\hline
\end{tabular}

Sea level: In this report, "sea level" refers to the National Geodetic Vertical Datum of 1929 (NGVD of 1929)--a geodetic datum derived from a general adjustment of the first-order level nets of both the United States and Canada, formerly called "Sea Level Datum of 1929." 


\title{
Reworking of Aggraded Debris Fans by the 1996 Controlled Flood on the Colorado River in Grand Canyon National Park, Arizona
}

\author{
By Robert H. Webb, Theodore S. Melis, Peter G. Griffiths, and John G. Elliott
}

\section{ABSTRACT}

Debris flows from 600 tributaries in Grand Canyon periodically deposit poorly sorted sediment on debris fans along the Colorado River between Lakes Powell and Mead. Before regulation, stable fans and rapids along the river resulted from the interaction of tributary debris flows and large, mainstem floods. Floods in the Colorado River maintained fans and rapids as highly-reworked deposits of boulders and cobbles. After the closure of Glen Canyon Dam in 1963, decreases in stage and stream power associated with reduced annual peak flows drastically reduced the amount of debris-fan reworking. Previous research has shown that modest powerplant releases from Glen Canyon Dam, particularly in combination with tributary floods, can significantly rework aggraded debris fans. These limited flows have entrained boulders up to $1 \mathrm{~m}$ in diameter, although discharges greatly exceeding the maximum powerplant release $\left(946 \mathrm{~m}^{3} / \mathrm{s}\right)$ would be required to completely remove most aggraded fans.

From 1987 through 1995, debris flows constricted the Colorado River at the mouths of at least 25 tributary canyons in Grand Canyon National Park, Arizona, creating 2 new rapids and narrowing at least 9 existing riffles or rapids. The highest peak discharge on the Colorado River in Grand Canyon between 1986 and 1996 was $960 \mathrm{~m}^{3} / \mathrm{s}$ in January 1993. In March-April 1996, we studied the effects of a 7-day flood release that peaked at $1,370 \mathrm{~m}^{3} / \mathrm{s}$ on 18 recently aggraded debris fans downstream from Glen Canyon Dam.

The largest changes occurred at Badger and Lava Falls rapids, 38 and $312 \mathrm{~km}$ downstream from the dam, respectively; several other aggraded debris fans were only slightly changed. Areas of aggraded debris fans decreased by 2 to 42 percent; only the debris fan at Bedrock Rapid, which is controlled by a large bedrock outcrop, increased in area owing to deposition of reworked sediment on the downstream margin. Volumes decreased on 7 of 9 debris fans by 3 to 34 percent. The distal margins of most recently aggraded debris fans became armored with a lag of cobbles and boulders, and the width of the reworked zone on most debris fans increased by 4 to $30 \mathrm{~m}$. Constriction of the river decreased at 11 of 18 debris fans, although some rapids, such as Tanner Rapid, became slightly more constricted at low discharges owing to changes in stage-discharge relations. Velocities on the left and right sides of Lava Falls Rapid decreased by about half, but velocities increased in three other rapids (e.g., Badger Creek Rapid). Stream power per unit width decreased in 9 of 10 rapids because of decreases in water-surface fall and widening of the rapids. Changes in the sizes of upper pool sand bars were inconsistent, although separation bars downstream from the reworked debris fan generally increased in size.

The amount of stream power generated by the controlled flood greatly affected the variability of reworking among the 18 debris fans. For a given discharge, mainstem reworking is expected to 
vary with channel and debris-fan geometry, the initial particle-size distribution of the deposit, and distance from the dam. The elapsed time between debris flow and the controlled flood also was important because larger particles at older deposits became interlocked, imbricated, and (or) sutured together during smaller dam releases combined with tributary floods in January 1993 and August 1994. The effectiveness of future floods of similar magnitude in reworking debris fans will depend in part on the release history and extent of armoring in the period between the debris flow and the flood. If reworking of debris fans is a criterion for design of future controlled floods, our data support release of a higher peak discharge of shorter duration shortly after constricting debris flows occur.

\section{INTRODUCTION}

Debris flows from 600 tributary canyons create and maintain the rapids of the Colorado River in Grand Canyon National Park, Arizona (Graf, 1980; Kieffer, 1985; Webb and others, 1988; Melis and others, 1994; Griffiths and others, 1996; Webb and others, 1996). Since 1986, the last year in which Glen Canyon Dam released at least $1,270 \mathrm{~m}^{3} / \mathrm{s}$, at least 25 debris flows have constricted the Colorado River in Grand Canyon (Melis and others, 1994), creating 2 new rapids and enlarging at least 9 existing riffles and rapids. The hydraulic settings range from small riffles to Lava Falls, the largest rapid in Grand Canyon (fig. 1; Webb and Melis, 1995; Webb and others, 1996). In general, deposition on debris fans increases flow velocities and water-surface fall through rapids (Melis and others, 1994; Webb, 1996), which changes the navigational severity of rapids and affects sand storage in eddies and upstream pools.

Before closure of Glen Canyon Dam in 1963, the Colorado River removed most of the deposits on aggraded debris fans during early summer floods that averaged $2,330 \mathrm{~m}^{3} / \mathrm{s}$ and were as large as 6,230 $\mathrm{m}^{3} / \mathrm{s}$ (fig. 2). All but the largest particles were swept downstream, and cobbles and small boulders were redeposited on debris bars that constrain the downstream extent of eddies (Howard and Dolan, 1981; Schmidt, 1990; Schmidt and Graf, 1990; Schmidt and Rubin, 1995) and control secondary rapids and riffles (Webb and others, 1989). The residual deposits formed boulder-laden debris fans that created rapids (fig. 3). The interaction between the frequency and magnitude of tributary debris flows and mainstem floods resulted in debris fans and rapids that were relatively stable. From 1963 through 1982, operations of Glen Canyon Dam constrained discharges to an average annual peak of $870 \mathrm{~m}^{3} / \mathrm{s}$, which allowed many debris fans to aggrade (Howard and Dolan, 1979, 1981). The large dam release of 1983, which was of a magnitude similar to pre-dam floods (fig. 2), reworked at least one aggraded debris fan (Kieffer, 1985).

In 1987, we began monitoring the reworking of aggraded debris fans (table 1; fig. 1; Melis and others, 1994; Webb and others, 1996), which numbered 16 by 1996 . Powerplant releases of up to $870 \mathrm{~m}^{3} / \mathrm{s}$ significantly reworked the distal margins of newly aggraded debris fans and armored older, previously reworked fans (fig. 4). Powerplant releases combined with a flood in the Little Colorado River in January 1993 resulted in boulders as large as $1 \mathrm{~m}$ in diameter being entrained (Melis and others, 1994) and increased the armoring of the distal margins of debris fans (fig. 4). Webb and others (1996) documented the complete removal of two historic debris fans at Lava Falls Rapid by dam releases; the first in 1965 by a dam release of $1,640 \mathrm{~m}^{3} / \mathrm{s}$ and the second in 1973 by a flow of $1,080 \mathrm{~m}^{3} / \mathrm{s}$. Cobbles and boulders entrained from the eroded debris fans appeared to be redeposited in the pool immediately downstream from Lava Falls rapid instead of on alternating bars farther downstream (fig. 3). This altered pattern of redeposition reflects a change in the geomorphic framework of the Colorado River (Webb, 1996).

Our objective is to quantify and record the effects of the 1996 controlled flood (Collier and others, 1997) on 18 debris fans and associated rapids in Grand Canyon National Park. We hypothesize that two types of reworking occur on aggraded debris fans: lateral bank collapse is most important on recently aggraded debris fans, whereas entrainment of individual particles is most 


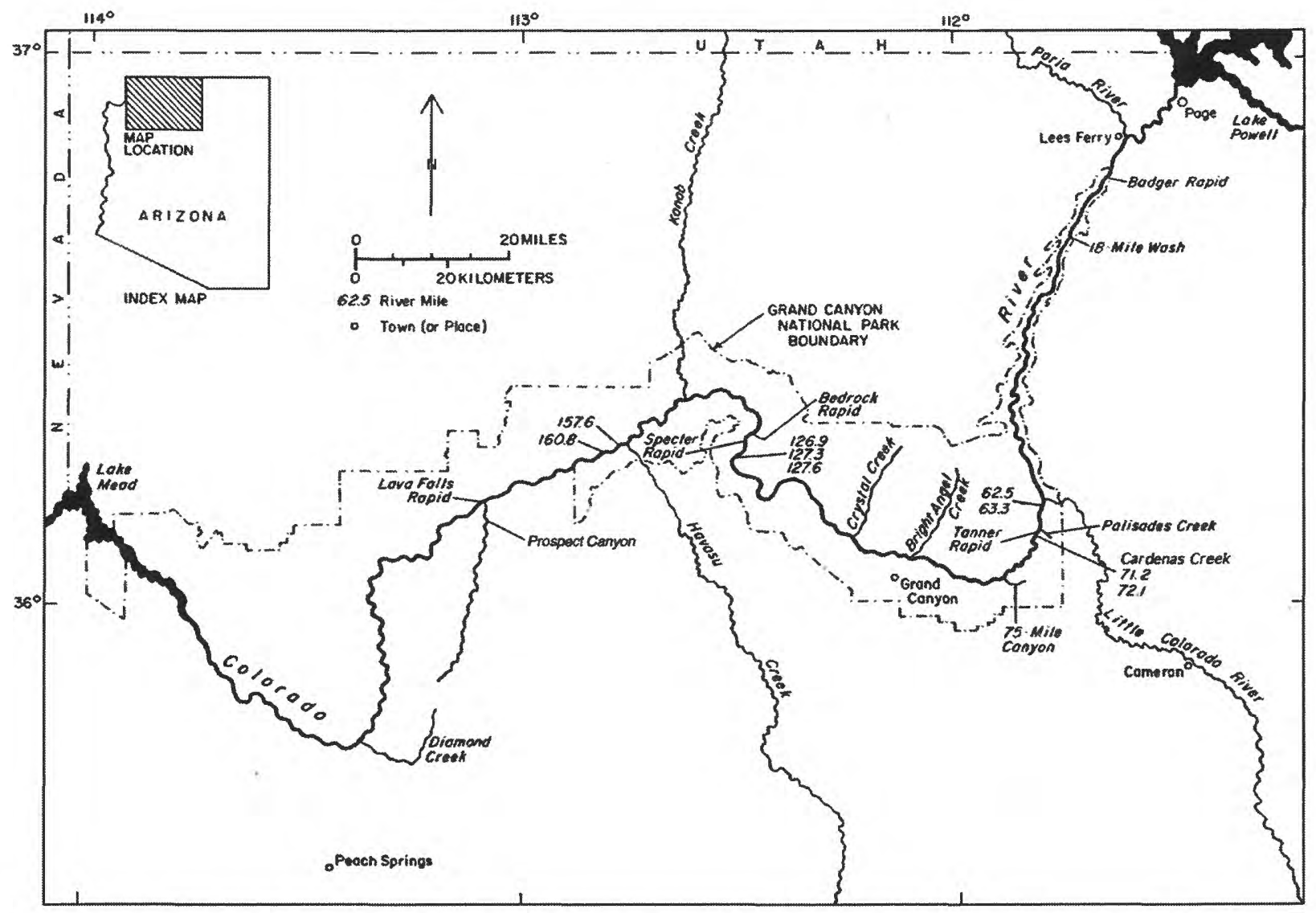

Figure 1. Map of the Colorado River in Grand Canyon showing the locations of debris fans monitored during the 1996 controlled flood.

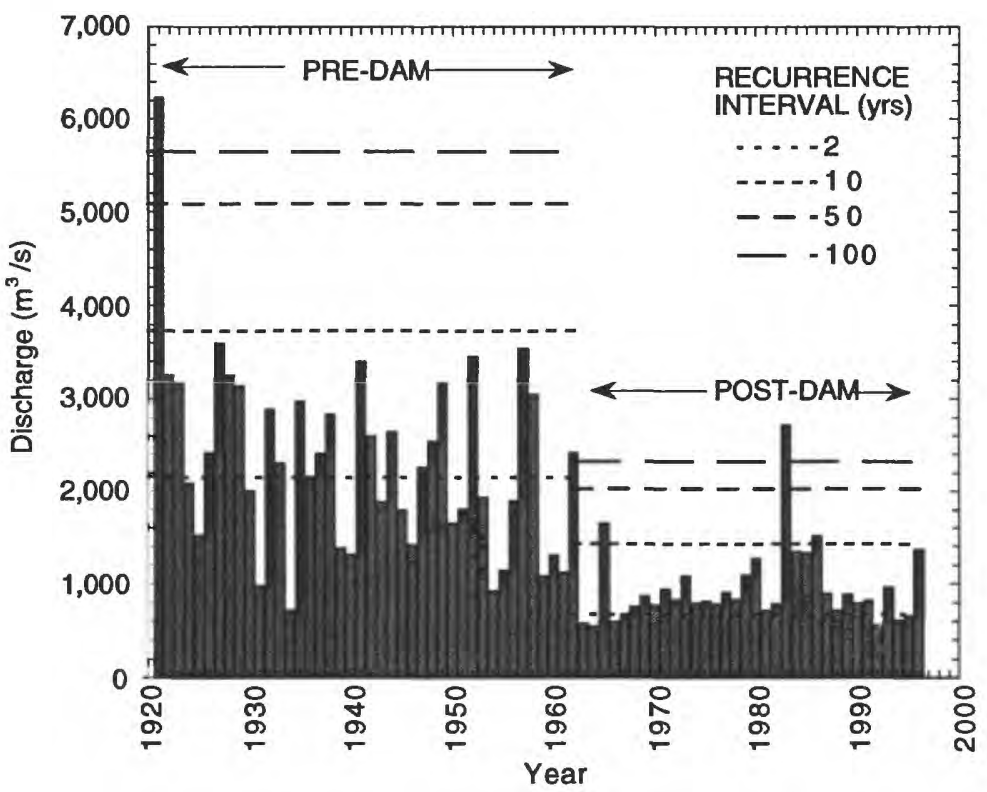

Figure 2. Annual flood series for the Colorado River near Grand Canyon, Arizona. After closure of Glen Canyon Dam in 1963, the mean annual flood decreased from 2,330 to $959 \mathrm{~m}^{3} / \mathrm{s}$. The 1996 controlled flood is about a 10-year flood in comparison with other annual maximum dam releases, but is only a 1.3-year flood on the unregulated Colorado River. The 1996 controlled flood was about half the size of the 1983 dam release but 20-50 percent larger than dam releases between 1986 and 1995 . 


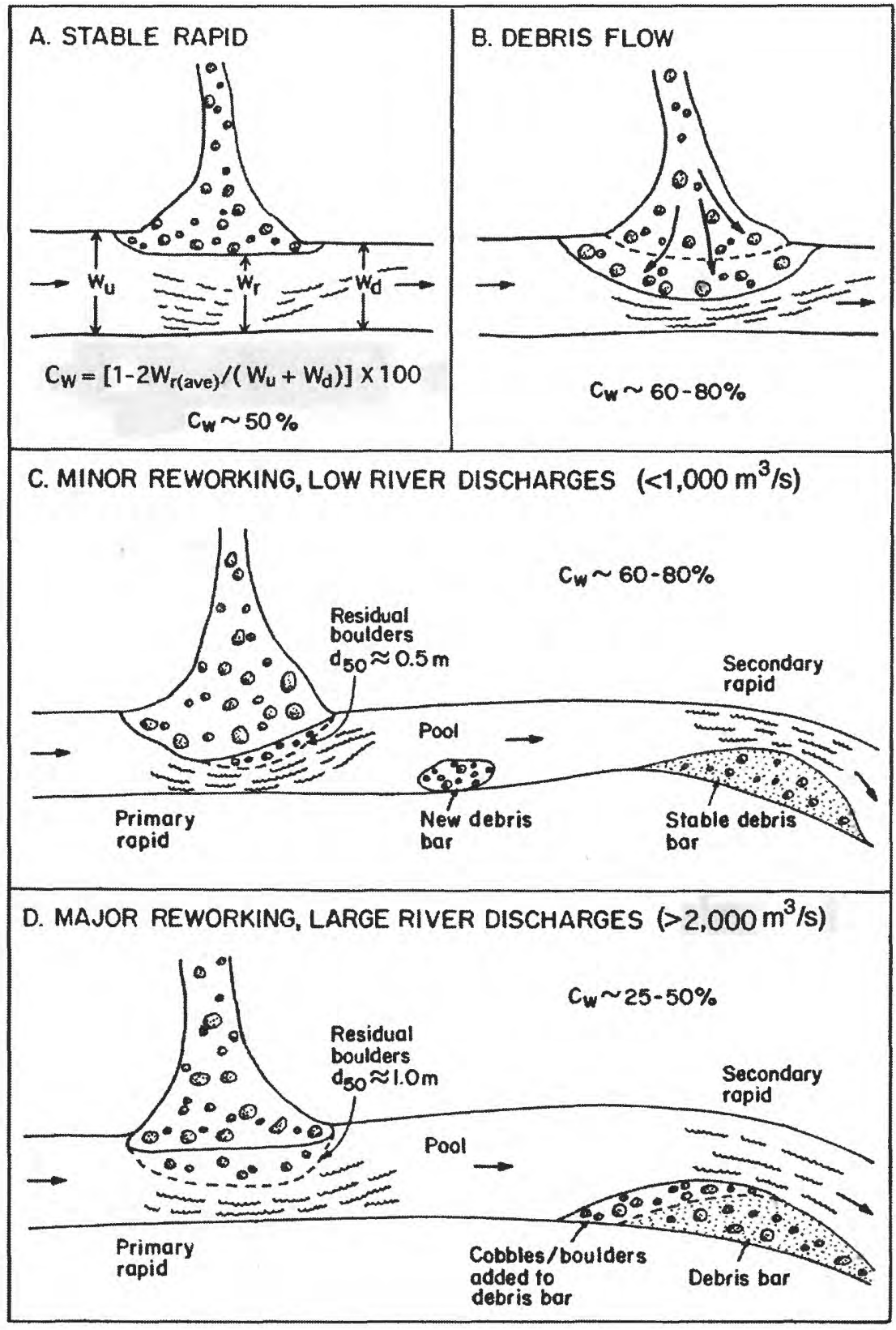

Figure 3. Schematic diagram showing a conceptual model of aggradation and reworking of a typical debris fan by the Colorado River in Grand Canyon. A typical fan-rapid system consists of a debris fan, a reach of whitewater, a downstream pool, and alternating bars farther downstream. This model is modified from Kieffer (1990) and Webb and others (1996). A, At stable rapids, the channel usually is constricted by 50 percent (Kieffer, 1985). B, Debris flows seldom dam the Colorado River. Instead, deposition generally constricts the river by 60-80 percent. The elevation of the bed rises, partly because boulders reworked from the debris fan are deposited in the main channel or near the opposite bank. C, Low discharges $\left(<1,000 \mathrm{~m}^{3} / \mathrm{s}\right)$ - whether small pre-dam floods or typical dam releases - may erode the distal margins of newly aggraded debris fans and widen the constriction. The degree of widening is dependent on local topographic conditions of the fan and mainstem channel, particularly the stage-discharge relation and water-surface fall, as well as the particle-size distribution of the debris-flow deposit. Debris eroded from the debris fan is deposited in the downstream pool. $D$, High discharges $\left(>2,000 \mathrm{~m}^{3} / \mathrm{s}\right)$ - large pre-dam floods or unusual dam releases such as in June 1983 - typically remove most of the new deposit, leaving a residual lag of boulders on the debris fan and in the widened rapid. At low discharges, the widened rapid may be more constricted than before the debris flow owing to the arrangement of immobile boulders and deposition on the downstream edge of the debris fan. Smaller boulders and cobbles are transported through the pool and deposited on the downstream debris bar. 
Table 1. Characteristics of debris fans aggraded after 1983 and associated rapids that were monitored during the 1996 controlled flood in Grand Canyon

\begin{tabular}{|c|c|c|c|c|c|c|c|c|c|c|c|}
\hline $\begin{array}{l}\text { Debris fan } \\
\text { (Rapid) }\end{array}$ & $\begin{array}{c}\text { River } \\
\text { mile }\end{array}$ & Side & $\begin{array}{c}\text { Year } \\
\text { of } \\
\text { debris } \\
\text { flow }\end{array}$ & $\begin{array}{l}\text { Amount" } \\
\text { of aggrad- } \\
\text { ation }\end{array}$ & $\begin{array}{c}\text { Previous } \\
\text { peak }^{*} \\
\text { discharge } \\
\left(\mathrm{m}^{3} / \mathrm{s}\right)\end{array}$ & $\begin{array}{c}\text { Fan } \\
\text { area }{ }^{\dagger}\end{array}$ & $\begin{array}{c}\text { Fan } \\
\text { volume }\end{array}$ & $\begin{array}{l}\text { Stream- } \\
\text { flow } \\
\text { velocity }\end{array}$ & $\begin{array}{c}\text { Particle } \\
\text { size } \\
\text { on distal } \\
\text { edge of fan }\end{array}$ & $\begin{array}{l}\text { Boulder } \\
\text { transport }\end{array}$ & $\begin{array}{l}\text { Particle } \\
\text { tracking }\end{array}$ \\
\hline $\begin{array}{l}\text { Jackass Canyon } \\
\text { (Badger Creek) }\end{array}$ & 7.9 & $\mathbf{L}$ & 1994 & C & 630 & $x$ & $x$ & $x$ & $\mathrm{x}$ & & \\
\hline 18 Mile & 18.0 & L & 1987 & S & 830 & $\mathrm{x}$ & $\mathrm{x}$ & $x$ & $\mathbf{x}$ & $\mathrm{x}$ & \\
\hline 62.5 Mile & 62.5 & $\mathbf{R}$ & 1990 & $\mathrm{C}$ & 960 & $x^{\S}$ & & & & & \\
\hline 63.3 Mile & 63.3 & $\mathbf{R}$ & 1990 & $\mathrm{C}$ & 960 & $x^{\S}$ & & & & & \\
\hline $\begin{array}{l}\text { Palisades Creek } \\
\text { (Lava Canyon) }\end{array}$ & 65.5 & $\mathbf{L}$ & $\begin{array}{l}1987 \\
1990\end{array}$ & D & 960 & $x^{\S}$ & & $\mathbf{x}$ & & $\mathrm{x}$ & \\
\hline $\begin{array}{c}\text { Tanner Canyon } \\
\text { (Tanner) }\end{array}$ & 68.5 & $\mathbf{L}$ & 1993 & C & 620 & $\mathbf{x}$ & $\mathrm{x}$ & $\mathbf{x}$ & $\mathrm{x}$ & $\mathrm{x}$ & \\
\hline Cardenas Creek & 70.9 & $\mathbf{L}$ & 1993 & D & 620 & $x^{\S}$ & & & & & \\
\hline 71.2 Mile & 71.2 & $\mathbf{R}$ & 1983 & C & 1,510 & $x^{\S}$ & & & & & \\
\hline 72.1 Mile & 72.1 & $\mathbf{R}$ & 1983 & C & 1,510 & $x^{\S}$ & & & & & \\
\hline $\begin{array}{c}\text { Crystal Creek } \\
\text { (Crystal) }\end{array}$ & 98.3 & $\mathbf{R}$ & 1995 & C & 720 & $x^{\S}$ & & & & & \\
\hline 126.9 Mile & 126.9 & L & 1989 & $\mathrm{C}$ & 960 & $\mathrm{x}$ & $\mathrm{x}$ & & $\mathbf{x}$ & & \\
\hline 127.3 Mile & 127.3 & L & 1989 & $\mathrm{C}$ & 960 & $x$ & $x$ & & $x$ & & \\
\hline 127.6 Mile & 127.6 & $\mathbf{L}$ & 1989 & C & 960 & $x$ & $x$ & $x$ & $\mathrm{x}$ & $x$ & \\
\hline $\begin{array}{l}\text { Specter Chasm } \\
\text { (Specter) }\end{array}$ & 129.0 & L & 1989 & $\mathrm{C}$ & 960 & $x^{\S}$ & & & & & \\
\hline $\begin{array}{c}\text { Bedrock Canyon } \\
\text { (Bedrock) }\end{array}$ & 130.0 & $\mathbf{R}$ & 1989 & $\mathrm{C}$ & 960 & $x^{\S}$ & & & & & \\
\hline 157.6 Mile & 157.6 & $\mathbf{R}$ & 1993 & $\mathrm{C}$ & 670 & $\mathrm{x}$ & $x$ & & $\mathrm{x}$ & $\mathrm{x}$ & \\
\hline 160.8 Mile & 160.8 & $\mathbf{R}$ & 1993 & D & 670 & $\mathrm{x}$ & $x$ & & $\mathrm{x}$ & $x$ & \\
\hline $\begin{array}{c}\text { Prospect Canyon } \\
\text { (Lava Falls) }\end{array}$ & 179.4 & L & 1995 & C & 670 & $\mathbf{x}$ & $x$ & $\mathbf{x}$ & $x$ & $\mathrm{x}$ & $\mathrm{x}$ \\
\hline
\end{tabular}

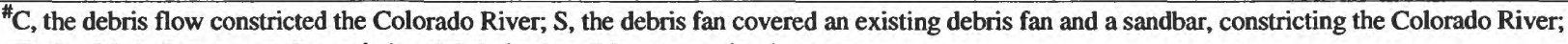
$D$, the debris flow covered an existing debris fan but did not constrict the river.

* Largest peak discharge on the Colorado River between the date of the debris flow and the 1996 controlled flood.

†Includes debris-fan area and areas of upper and lower sandbars. Except as noted, debris-fan area was measured using both ground surveys and rectification of registered aerial photographs.

${ }^{\S}$ Only determined by rectification of registered aerial photographs.

important on debris fans previously subjected to limited reworking. We document changes in debrisfan area and volume, particle-size distributions on the distal margins of debris fans, and surface velocities and water-surface fall through rapids. We evaluate the entrainment of individual cobbles and boulders in relation to changes in stream power and report transport distances of selected cobbles and boulders. Our results demonstrate the effectiveness of a discharge of $1,370 \mathrm{~m}^{3} / \mathrm{s}$ in reworking aggraded debris fans and provide data that may be useful in designing future controlled floods.

\section{Purpose and Scope}

This study provides an analysis of the effects of the 1996 controlled flood on aggraded debris fans in Grand Canyon National Park and vicinity, Arizona. The data presented here will be used as the basis for development of models of debris-fan reworking 


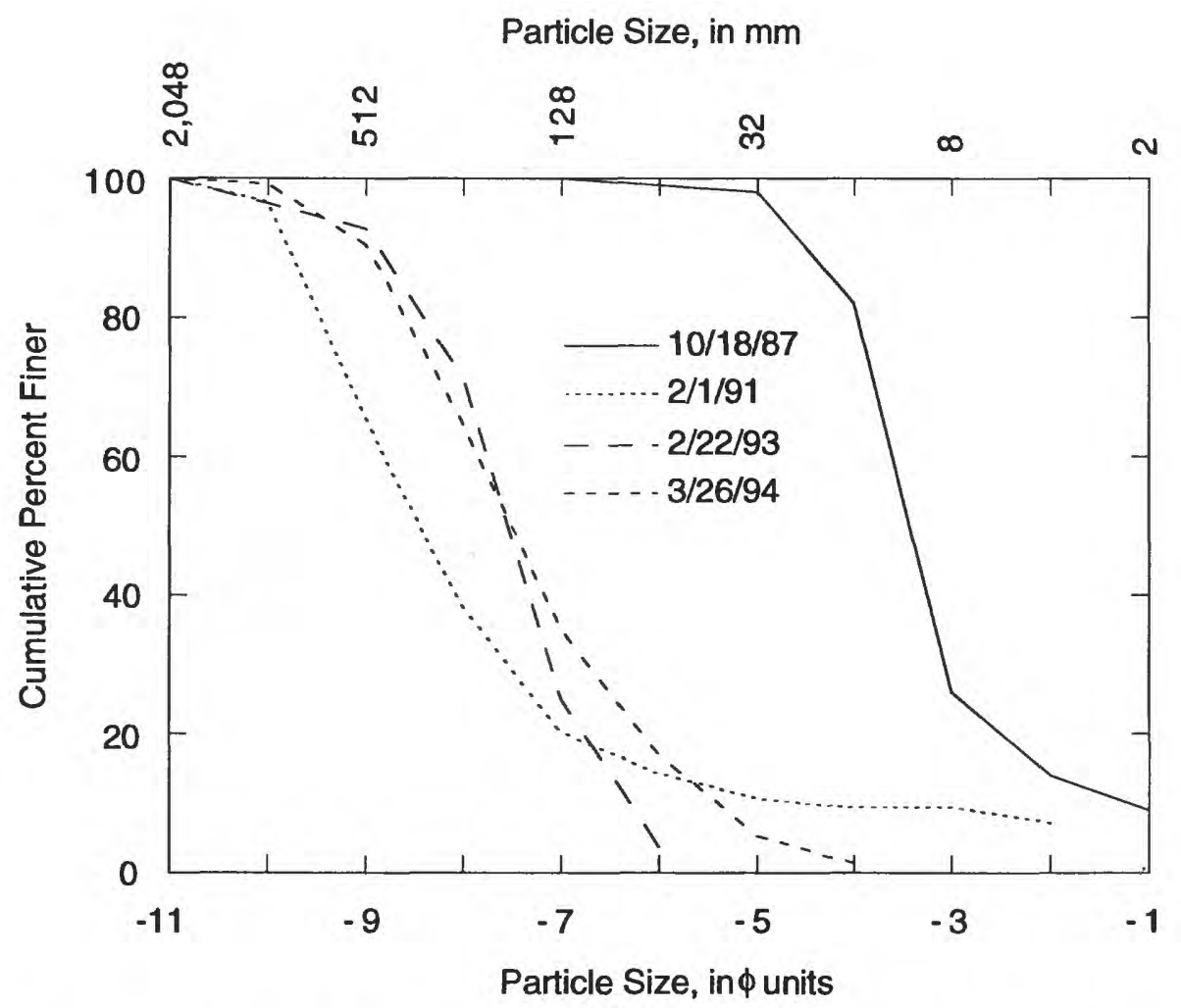

Figure 4. Particle-size distributions showing armoring of the distal margin of the aggraded debris fan at 18 Mile following the 1987 debris flow.

that may be useful in designing future controlled floods. This report incorporates some existing data on debris-fan reworking in Grand Canyon (Melis and others, 1994). This work was funded by and in cooperation with the Glen Canyon Environmental Studies Program of the Bureau of Reclamation (Wegner, 1991), partially in support of an environmental impact report on operations of Glen Canyon Dam (U.S. Department of the Interior, 1995).

\section{Units and Place Names}

In this report, we use the inch-pound unit of mile to describe the location of tributaries along the Colorado River; metric units are used for all other measures. Use of river mile has considerable historical precedent (Stevens, 1990) and provides a reproducible method of describing the location of tributaries with respect to the Colorado River. The location of tributaries was described using river miles downstream from Lees Ferry and a descriptor of " $L$ " for confluences on river-left and " $R$ " for river-right. The left and right sides of the Colorado River are determined as one faces downstream. We typically refer to "Grand Canyon" in broad reference to both Marble and Grand Canyons. "Marble Canyon" is the canyon reach of the Colorado River between Lees Ferry and the confluence with the Little Colorado River (river miles 0 to 61.5; fig. 1); we refer to Marble Canyon only for specific tributaries in that reach. Grand Canyon, which is formally designated for the reach between the confluence with the Little Colorado River and the Grand Wash Cliffs (river miles 61.5 to about 280), is considerably larger and better known than Marble Canyon.

\section{Acknowledgments}

The authors gratefully acknowledge the contributions the many individuals who helped with the field and office work that made this report possible. We thank Travis McGrath, Holly Metz, 
and Mia Wise, who were volunteers; Cassie Fenton of the University of Utah; Lauren Hammack, John Rihs, and Tamara Wiggins of the National Park Service; Joe Hazel of Northern Arizona University; Dominic Oldershaw, an independent contractor; Jim Pizzuto of the University of Delaware; Tim Randle of the Bureau of Reclamation; Robert Ruffner of the University of Minnesota; Steve Tharnstrom of the Defense Nuclear Agency; and Mimi Murov and Steve Wiele of the U.S. Geological Survey. We especially thank the professional river guides who made the difficult logistics possible: Tony Anderson, Steve Bledsoe, Kenton Grua, Bob Grusy, Matt Herman, Pete Reznick, Rachael Running, Kelly Smith, and Greg Williams. Bill Persons of the Arizona Game and Fish Department graciously loaned us radio telemetry receivers and antennas, and Lee Carstenson of Smith-Root, Incorporated, helped design our radio transmitters. The Defense Nuclear Agency generously provided Tharnstrom's salary for the duration of the flood experiment. Special thanks to Jim Pizzuto, Tim Randle and Jack Schmidt for their review of our manuscript. We also thank Dave Wegner of the Bureau of Reclamation for his support of our research.

\section{Effects of Debris Flows on the Colorado River}

Nearly all of the rapids of the Colorado River in Grand Canyon result from the accumulation of large boulders as debris fans at the mouths of side canyons that are deposited during tributary floods and debris flows (Péwé, 1968; Hamblin and Rigby, 1968; Simmons and Gaskill, 1969; Graf, 1979; Howard and Dolan, 1981), particularly debris flows (Webb and others, 1988, 1989; Melis and others, 1994). Debris flows have several important effects on the Colorado River (fig. 3). Large debris fans create rapids by constricting the width of the river and raising its bed elevation (Howard and Dolan, 1981). Deposition of unusually large boulders or arrangements of boulders on the bed of the rapid cause spectacular hydraulic features that impede navigation (Kieffer, 1985, 1987, 1990). These boulders are essentially permanent features of the rapids, having withstood historic discharges of up to $8,500 \mathrm{~m}^{3} / \mathrm{s}$ and possibly even larger prehistoric floods (O'Connor and others, 1994).

Some debris flows may aggrade the existing surface area of a debris fan without increasing the constriction of the Colorado River. This may change the stage-discharge relation for higher discharges without constricting the river at low discharges. Because the pattern of flow around the debris fan is altered at higher discharges, navigation through the rapid and sand deposition in eddies may also be changed (Melis and others, 1994). The lowwater control on the rapid - an arrangement of boulders on the bed and channel margin of the river - is not likely to be significantly reworked by dam releases, but higher deposits can be reworked, given sufficient discharges in the Colorado River.

Repeated debris-flow deposition alters the configuration of existing rapids and their controlling debris fans (Webb and others, 1989; Melis and others, 1994; Webb and others, 1996). Typically, zones of recirculating flow (eddies) form downstream from debris fans and facilitate the deposition of sand bars (Howard and Dolan, 1981; Schmidt, 1990). The unregulated Colorado River periodically widened constricted rapids by eroding boulders and debris-flow matrix from debris fans (Howard and Dolan, 1981). This reworking left behind residual debris-fan surfaces composed of large, immobile boulders overlain by alluvial sand (Melis and others, 1994).

During the reworking process in the unregulated river, sediment eroded from a debris fan, particularly cobbles and small boulders, was deposited downstream in an orderly array of debris bars (Howard and Dolan, 1981; Webb, 1996). Debris bars take the form of either low-water islands or alternating bars and are composed of well sorted and imbricated gravel, cobbles, or boulders. In comparison with initial debris-flow deposits on the fans, these graded deposits are also well-sorted in terms of particle lithology (Melis and others, 1994). Debris bars commonly form secondary rapids downstream of the larger, primary rapids located at tributary mouths (Webb and others, 1989). Secondary rapids are common in Grand Canyon, particularly below major rapids such as Hance, Granite, Crystal, and Lava Falls (river miles 76.7, 93.5, 98.2, and 179.4, respectively; Stevens, 1990). 
Many rapids in the Colorado River system have become more severe during the last 30 years because debris-fan constrictions and individual boulders cannot be totally removed by typical dam releases (Graf, 1980; Howard and Dolan, 1981; Melis and others, 1994; Webb, 1996). Péwé (1968) speculated that regulated flows would have minimal effects on debris-fan reworking, and that debris fans would therefore aggrade throughout Grand Canyon. By analyzing 1965 and 1973 aerial photographs, Howard and Dolan (1979) estimated that 27 percent of the debris fans in Grand Canyon had been aggraded by tributary floods. Graf (1980) hypothesized that debris fans on the Green River would aggrade or remain stable in response to operations of Flaming Gorge Dam. Melis and others (1994) also documented the aggradation of debris fans by debris flows and other floods in Grand Canyon as well as the reworking of selected fans by dam releases less than the maximum powerplant capacity of Glen Canyon Dam. Using field observations and 1-dimensional hydraulic modelling, Hammack (1994) documented the effects of the unregulated Yampa River on the reworking of Warm Springs Rapid, which was aggraded by a debris flow in 1966.

Kieffer (1985) presented a conceptual model of debris-fan reworking based on changes in Crystal Rapid that occurred during an extraordinary dam release in 1983. On the basis of this work, Kieffer concluded that stable debris fans in Grand Canyon constrict the channel by an average of 50 percent; she concluded that flows of about $11,300 \mathrm{~m}^{3} / \mathrm{s}$ would be required to rework Crystal Rapid to a stable constriction. At Warm Springs Rapid on the Yampa River in Colorado, Hammack and Wohl (1996) report that the 1965 debris flow, the largest in 1,000 years, was significantly reworked by a 1984 discharge of about 1,000 to $1,100 \mathrm{~m}^{3} / \mathrm{s}$, which likely had a recurrence interval of at least 50 years. They report that the duration of a flood is as important as its peak discharge in reworking aggraded debris fans. Webb and others (1996) documented several debris flows at Lava Falls Rapid that created constrictions similar to the one at Crystal Rapid and were reworked by flows less than or equal to $3,530 \mathrm{~m}^{3} / \mathrm{s}$. Webb and others (1996) modified Kieffer's conceptual model and suggested that dam releases above powerplant capacity but less than the annual pre-dam flood, such as the 1996 controlled flood, may partially or completely remove aggraded debris fans.

Before flow regulation, particles entrained from debris fans were transported downstream through the pool (fig. 3) and onto one of the alternating debris bars. The 1983 mainstem flood created a "rock garden" immediately downstream from Crystal Rapid (Kieffer, 1985) where previously a pool was present. Reworking by low discharges may cause deposition of particles in these pools, altering the pattern of recirculating flow or increasing the length of the rapid. We observed a similar phenomenon during the initial reworking of the newly aggraded Prospect Canyon debris fan (Webb and Melis, 1995; Webb and others, 1996).

\section{METHODS}

We assessed the amount of reworking by the 1996 controlled flood on 16 debris fans recently aggraded by debris flows and 2 other debris fans (table 1). These fans are distributed along the river corridor from Badger Creek to Lava Falls rapids (river miles 7.9 to 179.4 ; fig. 1) and represent a variety of geomorphic and hydraulic configurations. Debris flows at several sites, particularly 62.5 Mile, Tanner Canyon, $127.6 \mathrm{Mile}$, 157.6 Mile, and Prospect Canyon, initially constricted the river significantly. At 18 Mile, the 1987 debris flow covered both an existing debris fan and separation sandbar and significantly constricted the river. Some of the debris fans, particularly at Palisades Creek and 160.8 Mile, represent debris flows that covered existing debris fans without significantly increasing constriction of the river (table 1 ).

Most of these debris fans had experienced some reworking before the controlled flood by dam releases combined with tributary floods (Melis and others, 1994). Two debris fans - at 71.2 Mile and 72.1 Mile - were included despite reworking by discharges up to $1,510 \mathrm{~m}^{3} / \mathrm{s}$ in 1986 (fig. 2) and were not expected to be eroded by the 1996 controlled flood. The debris fan at Tanner Canyon, which was aggraded in August 1993, was mostly reworked by a dam release enhanced by a small flood in August 1994. The highest discharge that reworked 8 of the 18 debris fans was $960 \mathrm{~m}^{3} / \mathrm{s}$, 
which was a combination of a flood on the Little Colorado River and dam releases on January 13, 1993. Other debris fans had been reworked by dam releases that ranged from $620-830 \mathrm{~m}^{3} / \mathrm{s}$ (table 1 ). Debris fans at Crystal and Lava Falls rapids were aggraded in March 1995 and, because of their young age and poor sorting, were expected to change significantly during the 1996 controlled flood.

\section{Hydrographs of the Controlled Flood}

Discharge data were obtained from 3 gaging stations on the Colorado River during the controlled flood (fig. 5). We calculated pre- and post-flood discharges at all the monitored debris fans using known travel times between gaging stations at about $250 \mathrm{~m}^{3} / \mathrm{s}$ (Wiele, 1996; Wiele and Smith, 1996); for the peak of the flood, we report the highest discharge at the nearest gaging station. Flood frequency for unregulated and regulated periods of the record (1921-1962 and 1963-1996) was estimated at the gaging station on the Colorado River near Grand Canyon, Arizona (Garrett and Gellenbeck, 1991), using a log-Pearson type III distribution (U.S. Water Resources Council, 1981).

We obtained stage data for river flow through Lava Falls Rapid using a differential pressure transducer placed at the left bank at the head of the rapid. The data logger attached to the transducer recorded stage at $1 \mathrm{~min}$ intervals during the rising limb of the flood hydrograph and at $15 \mathrm{~min}$ intervals before, during, and after the flood. A similar stage recorder placed at 127.6 Mile provided a useful record of part of the rising limb before the transducer was destroyed. We compared the stage hydrograph at Lava Falls Rapid (river mile 179.4) with the discharge hydrograph at Diamond Creek (river mile 225.8; fig. 1) and found excellent agreement in the rising and falling limbs of the two records by decreasing the measurement time at Diamond Creek for all discharges by $7.46 \mathrm{hrs}$.

\section{Remote Sensing}

Photogrammetric analysis of aerial photographs, taken at steady river discharges of 230-260 $\mathrm{m}^{3} / \mathrm{s}$ before and after the controlled flood, was used to remotely assess changes in river constriction, surface area, and the width of the reworked zone at the 18 debris fans. Topographic control for debris fans between river miles 62 and 73 and for Crystal Rapid were obtained from digital orthophotographs (Glen Canyon Environmental Studies Program, unpublished data). For all other debris fans, we surveyed 9-12 control points on prominent rocks readily identified on low-level aerial photographs. Using image-processing software, which included ARC/INFO and the Map and Image Processing System (MIPS), we measured the plan area of each debris fan and the sandbars upstream and downstream, the change in width of the reworked distal edge of the debris fan, and the channel widths necessary to determine the constriction of the Colorado River. The reworked zone was observed as a band along the distal edge of a debris fan where an increase in surface texture indicated an increase in particle size.

The accuracy of image processing varied among the debris fans on the basis of the amount of distortion in the aerial photographs, the accuracy of surveyed or orthophotograph controls, the clarity of the image, and the choice of borders between debris fans, sandbars, and water stage in the Colorado River. The river discharge at each debris fan was not the same in the before- and after-flood aerial photography and is a source of error. Although the pixel resolution for the rectified images ranged from 0.1 to $0.5 \mathrm{~m}$, rectification involved the alteration of pixel locations by as many as several meters. For consistency, we rounded all area measurements to the nearest $100 \mathrm{~m}^{2}$ (implied accuracy of $\pm 50 \mathrm{~m}^{2}$ ) and all distance measurements to the nearest $1 \mathrm{~m}$ (implied accuracy of $\pm 0.5 \mathrm{~m}$ ).

\section{Surveying}

We surveyed 10 debris fans before and after the controlled flood to calculate changes in fan area, fan volume, and water-surface fall through the rapid. We calculate fan volume above the lowest elevation measured at the fan edge before the controlled flood. The accuracy of ground points is on the order of $\pm 0.1 \mathrm{~m}$ horizontally and $\pm 0.01 \mathrm{~m}$ vertically. Areas and volumes of debris fans were calculated using Sokkia MAP software. Although the accuracy of surveying data is higher than image- 

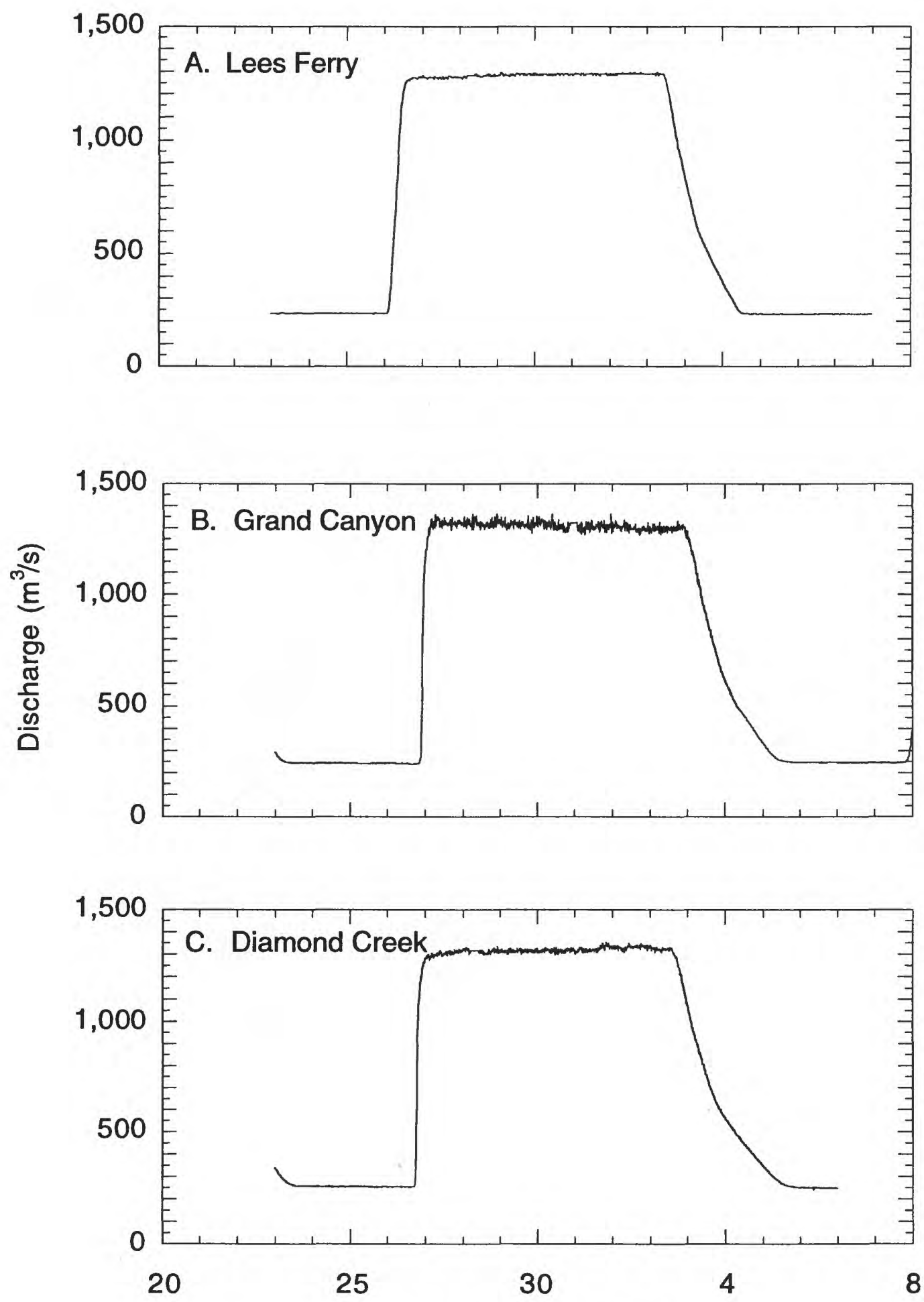

Day in March-April 1996

Figure 5. Hydrographs of the 1996 controlled flood at 3 gaging stations on the Colorado River downstream from Glen Canyon Dam in Grand Canyon. A, Colorado River at Lees Ferry. B, Colorado River near Grand Canyon. $C$, Colorado River above Diamond Creek near Peach Springs. 
processing data, for consistency we rounded all area measurements to the nearest $100 \mathrm{~m}^{2}$ (implied accuracy of $\pm 50 \mathrm{~m}^{2}$ ), all volume measurements to the nearest $100 \mathrm{~m}^{3}$ (implied accuracy of $\pm 50 \mathrm{~m}^{3}$ ), and all distance measurements to the nearest $1 \mathrm{~m}$ (implied accuracy of $\pm 0.5 \mathrm{~m}$ ).

\section{Constrictions}

The change in river constriction at a debris fan caused by reworking during the controlled flood was calculated as the percentage of channel width constricted by the debris fan (Webb and others 1996). The data for this technique were obtained using image processing and verified using survey data. We measured representative channel widths upstream from the rapid and downstream from the pool below the rapid, as well as $4-5$ channel widths of the most constricted section adjacent to the reworked margin of the debris fan.

We define percent constriction, $\mathrm{C}_{\mathrm{w}}$ (percent), as

$$
\mathrm{C}_{\mathrm{w}}=\left[1-2 \mathrm{~W}_{\mathrm{r}(\text { ave })} /\left(\mathrm{W}_{\mathrm{u}}+\mathrm{W}_{\mathrm{d}}\right)\right] \cdot 100
$$

where $\mathrm{W}_{\mathrm{r}(\text { ave })}=$ the average constricted channel width $(\mathrm{m}), \mathrm{W}_{\mathrm{u}}=$ the width upstream from the rapid $(\mathrm{m})$, and $\mathrm{W}_{\mathrm{d}}=$ the width downstream from the rapid (m) below the expansion zone. Although $\mathbf{C}_{\mathrm{w}}$ varies with river stage, we report $C_{w}$ at discharges before and after the controlled flood that varied between 230 and $260 \mathrm{~m}^{3} / \mathrm{s}$. The difference in discharge before and after the flood at each site was not enough to significantly affect the accuracy of the constriction values, which we considered to be \pm 0.5 percent for $\mathbf{C}_{\mathrm{w}}$.

We also calculated unit stream power, $\omega$ (w/ $\mathrm{m}^{2}$ ), before and after the flood at each rapid as

$$
\omega=\gamma \bullet Q \cdot S / W_{r(\text { ave })}
$$

where $\gamma=$ specific weight of water $\left(9,810 \mathrm{~N} / \mathrm{m}^{3}\right)$, $\mathrm{Q}=$ discharge $\left(\mathrm{m}^{3} / \mathrm{s}\right)$, and $\mathrm{S}=$ water-surface slope through the rapid (Baker and Costa, 1987). Slope was measured as the overall rapid slope from pool to pool surveyed at water's edge along the debris fan (except at Lava Falls Rapid where we surveyed on the bank opposite the debris fan).

\section{Measurements Before and After the Controlled Flood}

We used a variety of techniques to measure reworking of debris fans monitored before and after the controlled flood at discharges of about 250 $\mathrm{m}^{3} / \mathrm{s}$ (table 1). Point counts (Wolman, 1954) on the distal margins of 9 debris fans were used to document changes in particle-size distribution and armoring (Melis and others, 1994). Surveyed watersurface profiles documented changes in the watersurface fall through 10 rapids, which is dependent on both bed elevation and channel constriction. Overall changes in fan morphology were recorded with still photography at established monitoring stations

On 7 debris fans (table 1), selected boulders were marked with numbered bolts and surveyed for location during low discharges between 1994 and March 1996. The three principal axes, as well as appropriate dimensions for calculation of volume, and lithology of each particle were recorded. We then estimated particle volume and weight using appropriate mensuration formulae (Melis and others, 1994) and a particle density of $2,650 \mathrm{~kg} / \mathrm{m}^{3}$ for limestone and sandstone and $2,700 \mathrm{~kg} / \mathrm{m}^{3}$ for basalt. After the flood, the positions of marked boulders that remained above water level were resurveyed. On the Palisades Creek debris fan, we placed 190 particles that ranged in size from small cobbles to boulders (b-axis of $128-256 \mathrm{~mm}$ ). We recorded which particle sizes and lithologies were removed from the reworked surface by the flood.

We measured surface velocities before and after the controlled flood in selected riffles and rapids (table 1). For most of the measurements, we timed the movement of tetherballs released from shore or boats in lines down the center of the rapid or in specific boating runs, such as in Lava Falls Rapid. The configuration of the tetherball float did not affect the velocity measurement; the velocities obtained with partially deflated balls, fully inflated balls, and balls with attached carabinier clips were statistically identical. We attempted the velocity measurements at times when wind velocity was minimal. The length of the velocity test was measured either with tape measures stretched along the shore (an accuracy of $\pm 1 \mathrm{~m}$ over a distance of 40-70 m), or by survey (distances of 50-270 m) and 
timing was to the nearest $0.1 \mathrm{~s}$. Therefore, we estimated the accuracy of velocity measurements under ideal conditions to be on the order of $0.1 \mathrm{~m} / \mathrm{s}$. In some rapids, the velocity of the tetherballs was altered (or decreased to zero) by certain wave configurations, resulting in rejection of the measurement.

\section{Measurements During the Controlled Flood}

During the controlled flood, we measured debris-fan reworking at Palisades Creek, Tanner Canyon, and Prospect Canyon (Lava Falls Rapid). Water-surface profiles were surveyed periodically to determine the rate of change during the rise of the controlled flood. Surface velocities were measured occasionally during the rising limb of the flood at Lava Falls Rapid and during the steady high discharge at all three rapids. At Tanner Rapid, we timed driftwood for streamflow velocity measurements during the peak of the controlled flood.

Before the flood at Lava Falls Rapid, radio transmitters (tags) were cemented into 9 selected particles on the distal fan margin that would be inundated by discharges between $250-280 \mathrm{~m}^{3} / \mathrm{s}$; a radio tag was attached to the outside of a 10th particle. Three of the 10 particles were cobble size (less than $256 \mathrm{~mm}$ ); the rest were boulders (greater than $256 \mathrm{~mm}$ ). We used specially built radio tags transmitting in the 40-Mhz waveband with a battery life of 30 days for maximum transmission power (Lee Carstenson, Smith-Root, Incorporated, oral commun., 1996). We measured the topographic pockets occupied by these particles (Wiberg and Smith, 1987) before the flood and the topography of the reworked margin after the flood. The time of initial motion during the flood was documented using both a scanning receiver attached to a data logger and an audible receiver. Radio signals from dislodged particles were faint during the controlled flood because of signal attenuation in the deep water. Weak to strong signals were detected during the steady low discharges after the flood. By triangulation with manual receivers, we located 8 of 10 radio-tagged particles after the flood. We estimated that the accuracy of the particle location to be within at least a $5 \mathrm{~m}$ radius. The accuracy of our relocation varied with water depth, which we did not determine.

\section{RESULTS}

\section{Hydrographs of the 1996 Controlled Flood}

The 1996 controlled flood was designed to consist of 5 release periods from Glen Canyon Dam: an initial steady flow of $226 \mathrm{~m}^{3} / \mathrm{s}$ for 4 days; a rapid rise at a rate of $113 \mathrm{~m}^{3} \mathrm{~s}^{-1} \mathrm{hr}^{-1}$; a steady flow of $1,270 \mathrm{~m}^{3} / \mathrm{s}$ for 7 days; a 3-stage downramping period (of no relevance to this study); and a concluding steady flow of $226 \mathrm{~m}^{3} / \mathrm{s}$ for 4 days (Glen Canyon Environmental Studies Program, written commun., 1996). The hydrograph and discharges measured at 3 gaging stations below the dam differed somewhat from the design characteristics of the controlled flood (fig. 5). The initial period had discharge ranges of 231-238, 239 250 , and $252-258 \mathrm{~m}^{3} / \mathrm{s}$ at Lees Ferry, Grand Canyon, and Diamond Creek, respectively. The ranges in peak discharges were 1,270-1,300, 1,2701,370 , and $1,300-1,350 \mathrm{~m}^{3} / \mathrm{s}$ at these stations, respectively (fig. 5). Finally, the concluding period had discharge ranges of 229-234, 244-251, and $242-253 \mathrm{~m}^{3} / \mathrm{s}$ at Lees Ferry, Grand Canyon, and Diamond Creek, respectively (fig. 5). The differences between the gaging stations are probably related to errors in the stage-rating curves of the gaging stations, contributions of tributary inflows, and flow attenuation.

The discharge hydrograph for JanuarySeptember, 1996, is considerably different from typical dam releases, recent dam releases with tributary inflows, and a comparable pre-dam period (fig. 6). The peak discharge of $1,370 \mathrm{~m}^{3} / \mathrm{s}$ at the Colorado River near Grand Canyon gaging station during the 1996 controlled flood was approximately a 10-year flood for the regulated Colorado River but only a 1.3-year flood on the unregulated river (fig. 2). A 10-year flood on the unregulated Colorado River was approximately $3,390 \mathrm{~m}^{3} / \mathrm{s}$ and had a considerably longer flow duration and higher flow volume (fig. 6). The largest peak discharge on the mainstem since $1986\left(966 \mathrm{~m}^{3} / \mathrm{s}\right)$ occurred in January 1993, which is a 3-year flood in the post- 


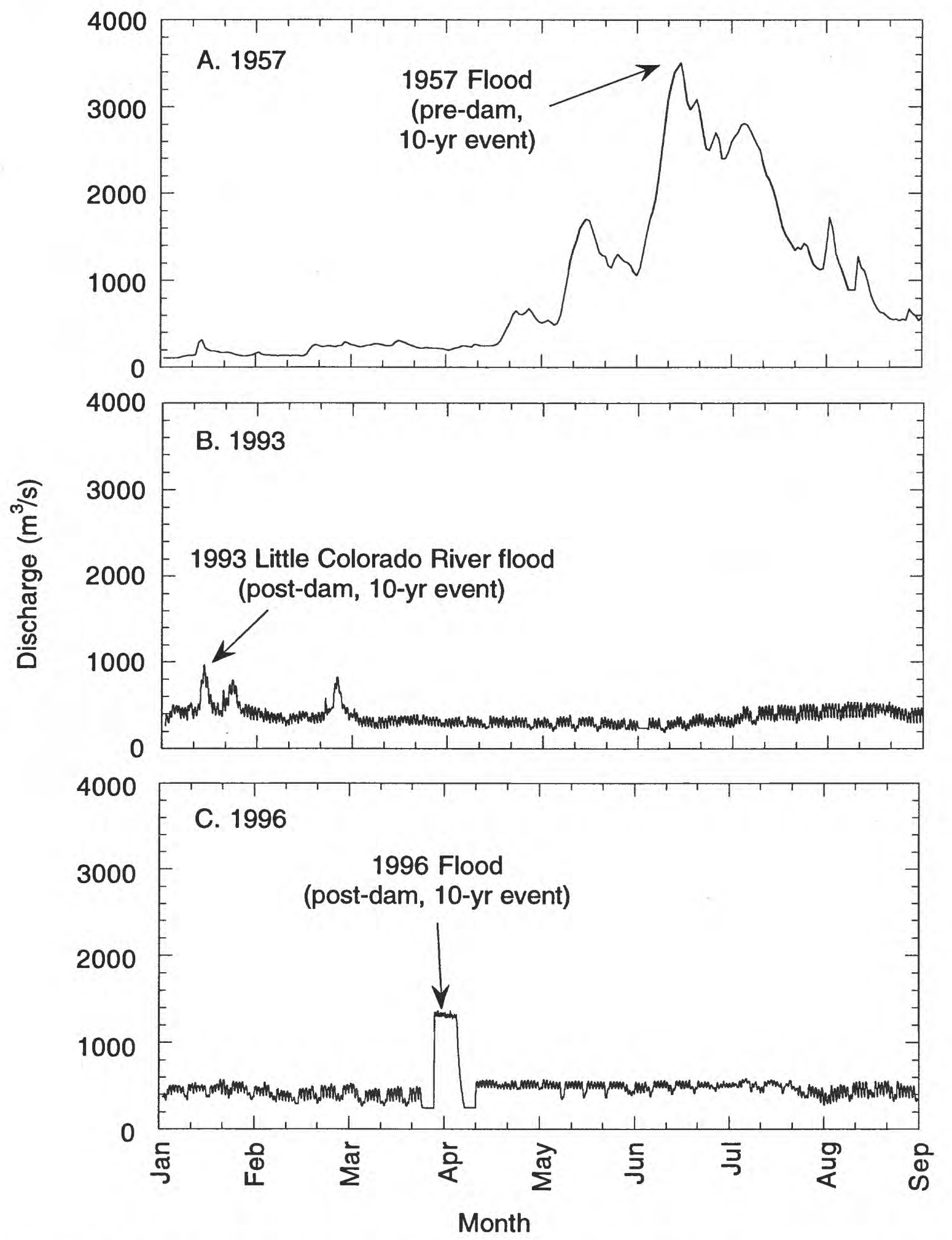

Figure 6. Hydrographs of the Colorado River near Grand Canyon showing A, the January-September hydrographs of a pre-dam flood in 1957. B, dam releases augmented by a 10-year flood on the Little Colorado River in 1993, and $C$, the 1996 controlled flood. The peak discharges of the 1957 and the 1996 floods are 10-year events in the pre-dam and post-dam periods, respectively. 

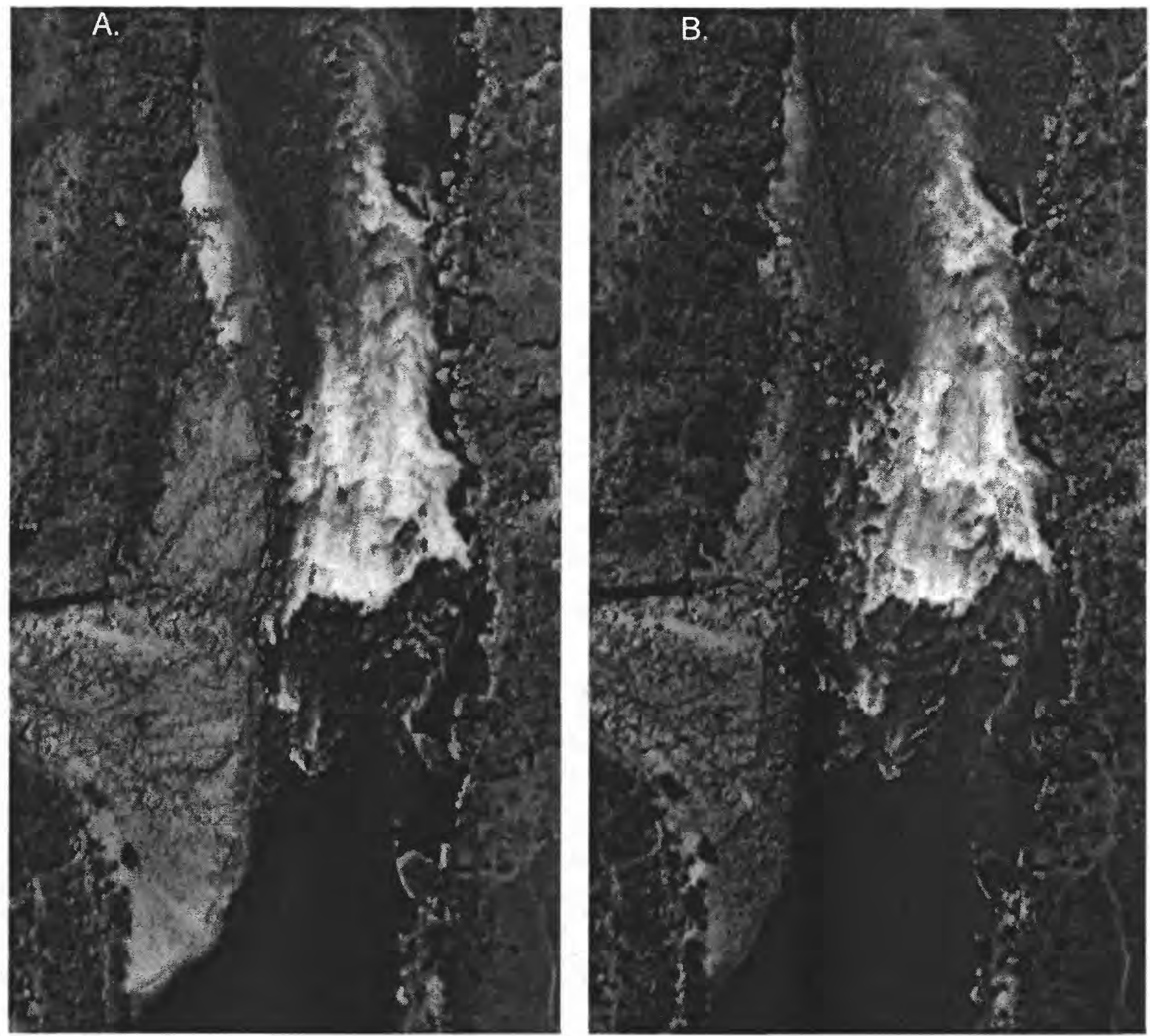

Figure 7. Aerial photographs that document reworking of the Prospect debris fan at Lava Falls Rapid. A, (March 24, 1996). Lava Falls Rapid was constricted by a 1995 debris flow from Prospect Canyon, shown on the left. The discharge is about $254 \mathrm{~m}^{3} / \mathrm{s}$. B, (April 9, 1996). Reworking during the rising limb of the 1996 controlled flood removed $5,900 \mathrm{~m}^{3}$ of the edge of the debris fan, increasing the width of the rapid by an average of $5 \mathrm{~m}$. The surface velocities on the right and left sides decreased by one half. The discharge is about $246 \mathrm{~m}^{3} / \mathrm{s}$.

dam period but less than the mean annual pre-dam flood.

\section{Relation Between the Hydrograph and Reworking at Lava Falls Rapid}

In March 1995, a debris flow from Prospect Canyon, the sixth to occur since 1939 (Webb and others, 1996), constricted the Colorado River at Lava Falls Rapid (fig. 1; Webb and Melis, 1995). After an initial reworking in the days immediately following this debris flow, the newly aggraded debris fan had an area of $5,300 \mathrm{~m}^{2}$ and a volume of $32,900 \mathrm{~m}^{3}$ (tables 2 and 3). During the 1996 controlled flood, the area and volume of the debris fan decreased by 21 and 18 percent, respectively (fig. 7).

We observed debris-fan reworking at Lava Falls Rapid during the controlled flood and noted the relation between the period of active erosion and the hydrograph (fig. 8). As the discharge rose on the morning of March 27, the stage increased accordingly until a discharge of about $1,000 \mathrm{~m}^{3} / \mathrm{s}$ (about $1200 \mathrm{hrs}$ ). The stage was approximately 0.2 to $0.5 \mathrm{~m}$ less than the top of the aggraded debris fan, 


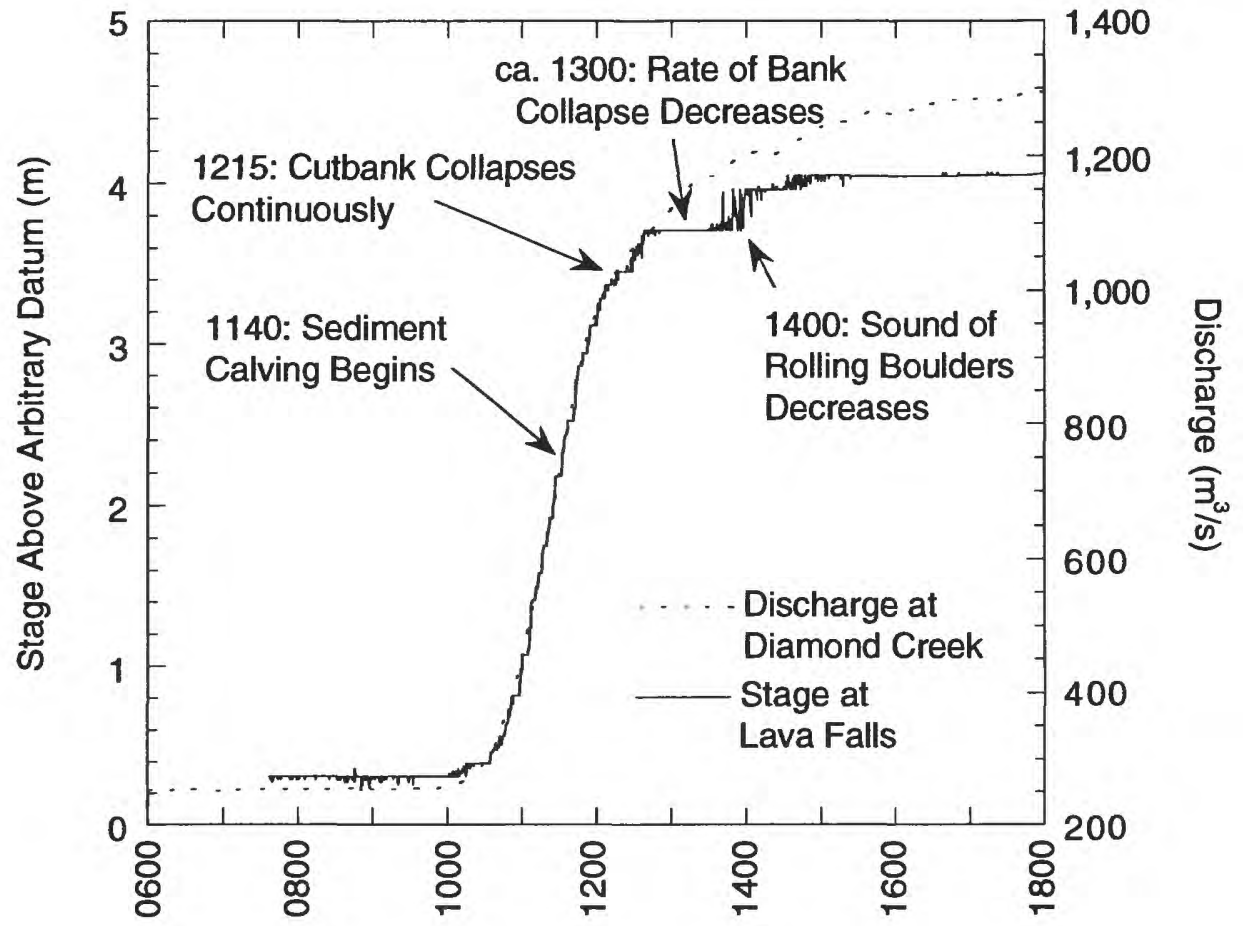

Time on March 27, 1996

Figure 8. The relation between stage, discharge, and reworking of the debris fan at Lava Falls Rapid. The stage record at Lava Falls Rapid is for March 27, 1996, and the hydrograph for the Colorado River above Diamond Creek is adjusted for a discharge-independent travel time of $7.46 \mathrm{hrs}$.

and we observed the beginning of bank collapse by slab failures at $1140 \mathrm{hrs}$. Bank collapse began on the downstream side of the debris fan. By $1200 \mathrm{hrs}$, the cutbank of the aggraded debris fan was continuously collapsing, and the stage record flattened to nearly zero change with time despite an increasing discharge (fig. 8). For about an hour, boulders could be heard rolling along the bed of the river away from the debris fan. Bank collapse greatly decreased in frequency by $1300 \mathrm{hrs}$, and boulders were heard rolling only occasionally by $1400 \mathrm{hrs}$. As reworking slowed, the stage began rising again, tracking the slow rise in discharge (fig. 8).

\section{Areas and Volumes of Debris Fans}

The areas of recently aggraded debris fans in Grand Canyon generally decreased during the controlled flood (table 2). The largest changes were in the debris fans at Jackass Canyon (Badger Creek Rapid) and Prospect Canyon (Lava Falls Rapid; fig. 7). In both cases, the debris flow occurred less than 2 years before the controlled flood, and previous river discharges were too low to significantly rework these deposits. Decreases in fan area were observed at most of the rapids, but the area of the debris fan at Bedrock Canyon increased slightly because reworked sediment was deposited at the downstream margin of the debris fan. As expected, the debris fan at 71.2 Mile, which had been reworked at higher discharges (table 1), was unchanged. The debris fan at 72.1 Mile had also been partially reworked previously, but lost $100 \mathrm{~m}^{2}$ of fan area during the controlled flood.

Although we obtained considerable agreement between our two methods of measuring debris-fan area, areas calculated using image processing differed slightly from those measured by topographic survey for some debris fans (table 2). For example, at $18 \mathrm{Mile,}$ we observed no changes in 
Table 2. Change in areas of debris fans reworked by the 1996 controlled flood in Grand Canyon

\begin{tabular}{|c|c|c|c|c|c|c|}
\hline \multirow[b]{2}{*}{ Debris fan } & \multicolumn{3}{|c|}{ IMAGE PROCESSING } & \multicolumn{3}{|c|}{ SURVEYED } \\
\hline & $\begin{array}{l}\text { Pre-flood } \\
\text { area }\left(m^{2}\right)\end{array}$ & $\begin{array}{l}\text { Post-flood } \\
\text { area }\left(\mathrm{m}^{2}\right)\end{array}$ & $\begin{array}{l}\text { Difference } \\
\text { (\%) }\end{array}$ & $\begin{array}{l}\text { Pre-flood } \\
\text { area }\left(m^{2}\right)\end{array}$ & $\begin{array}{l}\text { Post-flood } \\
\text { area }\left(m^{2}\right)\end{array}$ & $\begin{array}{l}\text { Difference } \\
\text { (\%) }\end{array}$ \\
\hline Jackass Canyon ${ }^{*}$ & 1,900 & 1,100 & -42 & 1,900 & 1,100 & -42 \\
\hline 18 Mile & 4,300 & 4,300 & 0 & 4,200 & 4,000 & -5 \\
\hline 62.5 Mile & 1,600 & 1,500 & -6 & ns & ns & $\mathrm{ns}$ \\
\hline $63.3 \mathrm{Mile}^{\dagger}$ & 1,400 & 1,300 & -7 & ns & ns & ns \\
\hline Palisades Creek ${ }^{\dagger}$ & 2,300 & 2,300 & 0 & ns & ns & ns \\
\hline Tanner Canyon ${ }^{\#}$ & 2,100 & 2,100 & 0 & 2,000 & 1,900 & -5 \\
\hline Cardenas Creek $^{\#}$ & 7,800 & 7,900 & +1 & ns & ns & ns \\
\hline $71.2 \mathrm{Mile}^{\S}$ & 4,400 & 4,400 & 0 & ns & ns & $\mathrm{ns}$ \\
\hline $72.1 \mathrm{Mile}^{\S}$ & 1,500 & 1,400 & -7 & ns & ns & ns \\
\hline Crystal Creek $^{* *}$ & 5,300 & 5,200 & -2 & ns & ns & ns \\
\hline 126.9 Mile & 3,100 & 3,100 & 0 & 3,200 & 3,200 & 0 \\
\hline 127.3 Mile & 2,100 & 2,100 & 0 & 2,000 & 1,900 & -5 \\
\hline 127.6 Mile & 3,000 & 2,700 & -10 & 3,300 & 2,800 & -15 \\
\hline Specter Chasm & 3,800 & 3,400 & -10 & ns & ns & ns \\
\hline Bedrock Canyon & 3,000 & 3,200 & +7 & ns & ns & ns \\
\hline 157.6 Mile & 3,600 & 3,100 & -14 & 3,400 & 3,300 & -3 \\
\hline 160.8 Mile & 4,200 & 4,100 & -2 & 4,100 & 3,700 & -10 \\
\hline Prospect Canyon ${ }^{* *}$ & 5,000 & 4,000 & -20 & 5,300 & 4,200 & -21 \\
\hline
\end{tabular}

Except as noted, all areas are of the entire debris fan. ns, not surveyed.

*Only the area of 1994 deposition (Melis and others, 1994).

tOnly the area of 1990 deposition (Melis and others, 1994).

\#Only the area of 1993 deposition (Melis and others, 1994).

${ }^{8}$ This debris fan was not expected to change during the controlled flood (see Methods section).

** Only the area of 1995 deposition (Webb and others, 1996)

the size of debris fans using image processing, but we measured a decrease of $200 \mathrm{~m}^{2}$ in area by surveying before and after the flood. The quality of the aerial photographs taken before and after the flood, as well as photographic clarity of the fanwater boundary, are extremely important in the area calculations using image processing. How the boundary between aggraded debris fan and old debris fan and sand bars is delineated also affects the results from both methods.

In general, changes in debris-fan volumes mirrored changes in areas (table 3). The debris fan at Lava Falls Rapid lost the largest volume of sediment $\left(5,900 \mathrm{~m}^{3}\right)$, whereas the new deposits on the Jackass Canyon debris fan had the largest percentage change ( -34 percent). In most cases, the changes in area and volume accurately depict floodreworked conditions on the debris fans except for 160.8 Mile, where a considerable volume of fine sediment, mostly debris-flow matrix of particles less than $16 \mathrm{~mm}$ in diameter, was eroded from between boulders that were present before the 1993 debris flows. This type of erosion cannot readily be accounted for using surveying or image-processing techniques. We had few inconsistencies between the changes in area and volume except at 126.9 Mile, for which the survey data showed no change in volume yet a $200 \mathrm{~m}^{2}$ decrease in area. Deposits that are poorly sorted contain large numbers of boulders, and have irregular boundaries are difficult to describe using standard techniques.

\section{Armoring of the Distal Margins of Debris Fans}

Armoring of the distal margin was evaluated at 9 debris fans (table 4). Most debris fans showed 
Table 3. Change in volumes of debris fans reworked by the 1996 controlled flood in Grand Canyon

\begin{tabular}{|c|c|c|c|c|}
\hline Debris fan & $\begin{array}{l}\text { Pre-flood } \\
\text { volume }\left(\mathrm{m}^{3}\right)\end{array}$ & $\begin{array}{c}\text { Post-flood } \\
\text { volume }\left(\mathrm{m}^{3}\right)\end{array}$ & $\begin{array}{c}\text { Volume } \\
\text { eroded }\left(m^{3}\right)\end{array}$ & $\begin{array}{c}\text { Difference } \\
(\%)\end{array}$ \\
\hline Jackass Canyon $^{*}$ & 5,800 & 3,800 & 2,000 & -34 \\
\hline 18 Mile & 16,800 & 14,900 & 1,900 & -11 \\
\hline Tanner Canyon $^{\dagger}$ & 7,200 & 6,700 & 500 & -7 \\
\hline 126.9 Mile & 15,700 & 15,700 & 0 & 0 \\
\hline 127.3 Mile & 8,800 & 8,500 & 300 & -3 \\
\hline 127.6 Mile & 13,100 & 11,500 & 1,600 & -12 \\
\hline 157.6 Mile & 9,800 & 7,900 & 1,900 & -19 \\
\hline 160.8 Mile & 13,500 & 13,500 & 0 & 0 \\
\hline Prospect Canyon ${ }^{8}$ & 32,900 & 27,000 & 5,900 & -18 \\
\hline
\end{tabular}

Except as noted, all volumes are of the entire debris fan.

* Only the volumes of 1994 deposition (Melis and others, 1994).

†Only the volume of 1993 deposition (Melis and others, 1994).

\&Only the volume of the lowest part of the debris fan, which was covered by the 1995 deposition (Webb and others, 1996).

Table 4. Change in particle-size distributions on the distal margins of debris fans reworked by the 1996 controlled flood in Grand Canyon

\begin{tabular}{|c|c|c|c|c|c|}
\hline Debris fan & $\begin{array}{c}\text { Year of } \\
\text { debris flow }\end{array}$ & $\begin{array}{l}\text { Particle } \\
\text { diameter }\end{array}$ & $\begin{array}{c}\text { Debris flow } \\
\text { deposit ( } \mathrm{mm})\end{array}$ & $\begin{array}{l}\text { Before flood } \\
(\mathrm{mm})\end{array}$ & $\begin{array}{l}\text { After flood } \\
(\mathrm{mm})\end{array}$ \\
\hline \multirow[t]{2}{*}{ Jackass Canyon } & 1994 & $D_{50}$ & 110 & 140 & 220 \\
\hline & & $D_{85}$ & 480 & 470 & 540 \\
\hline \multirow[t]{2}{*}{18 Mile } & 1987 & $D_{50}$ & 11 & 180 & 170 \\
\hline & & $D_{85}$ & 18 & 410 & 440 \\
\hline \multirow[t]{2}{*}{ Tanner Canyon } & 1993 & $D_{50}$ & 71 & 89 & 160 \\
\hline & & $D_{85}$ & 290 & 550 & 540 \\
\hline \multirow[t]{2}{*}{ 126.9 Mile } & 1989 & $D_{50}$ & 31 & 81 & 82 \\
\hline & & $D_{85}$ & 110 & 290 & 310 \\
\hline \multirow[t]{2}{*}{ 127.3 Mile } & 1989 & $D_{50}$ & $54^{*}$ & $54^{*}$ & 89 \\
\hline & & $D_{85}$ & $170^{*}$ & $170^{*}$ & 240 \\
\hline \multirow[t]{2}{*}{ 127.6 Mile } & 1989 & $D_{50}$ & 10 & 170 & 260 \\
\hline & & $D_{85}$ & 86 & 440 & 620 \\
\hline \multirow[t]{2}{*}{ 157.6 Mile } & 1993 & $D_{50}$ & 120 & 180 & 180 \\
\hline & & $D_{85}$ & 360 & 470 & 410 \\
\hline \multirow[t]{2}{*}{160.8 Mile } & 1993 & $D_{50}$ & 150 & 140 & 190 \\
\hline & & $D_{85}$ & 480 & 410 & 530 \\
\hline \multirow[t]{2}{*}{ Prospect Canyon } & 1995 & $D_{50}$ & 140 & 210 & 530 \\
\hline & & $D_{85}$ & 370 & 650 & 1170 \\
\hline
\end{tabular}

*Particle size measured in March 1994 because a 1993 tributary flood altered the particle-size distribution of the distal margin of the debris fan (Melis and others, 1994). 
significant increases in the sizes of particles in the reworked zones (figs. 9, 10, 11B, and 11C). The $\mathrm{D}_{50}$ of particles decreased, remained unchanged, or increased only slightly for some debris fans, such as the debris fans at 18 Mile, 126.9 Mile, 157.6 Mile and 160.8 Mile. But $D_{50}$ increased by up to a factor of 2.5 at others, including Jackass Canyon and Prospect Canyon. The increases in $\mathrm{D}_{85}$ were generally greater; the typical $D_{85}$ after the controlled flood was about $0.5 \mathrm{~m}$ but was as high as $1.2 \mathrm{~m}$ at Prospect Canyon (table 4).

At Lava Falls Rapid, $\mathrm{D}_{50}$ on the Prospect Canyon debris fan increased from $0.21 \mathrm{~m}$ to $0.53 \mathrm{~m}$ during the controlled flood (table 4). As a result of reworking, the particles on the distal margin of the debris fan became larger and better sorted (fig. 12a). Reworking also preferentially removed limestones, leaving a deposit dominated by basalt particles (fig. 12b). These results are in agreement with Melis and others (1994), who report similar preferential lithologic removal during reworking.

The width of the reworked zone on the debris fan was one of the most sensitive measurements of the effects of the 1996 controlled flood (table 5). For 12 of the debris fans, the width of the reworked zone increased by at least 4-14 $\mathrm{m}$ (the increase of 30 $\mathrm{m}$ at Crystal Rapid occurred over a relatively small and low-relief debris fan deposited in 1995). For many of the debris fans, the reworked zone after the flood was at least twice as wide as it was before the flood (table 5). The width of the reworked zone at Jackass Canyon (Badger Rapid) decreased because a third of the aggraded debris fan was removed by the controlled flood. We measured no change in the width of the reworked zone at Palisades Creek and 127.3 Mile. Changes in the size of the reworked zone are likely dependent on local stage-discharge relations during the controlled flood.

\section{Constriction, Velocities, Water-Surface Fall, and Stream Power}

Of the 18 debris fans we monitored, the percent constriction, $\mathrm{C}_{\mathrm{w}}$, decreased at 11 sites (table 6), indicating widening of the rapid and (or) changes in the stage-discharge relation. The largest amount of widening occurred at Prospect Canyon and 62.5 Mile, where changes in constriction were nearly 20 percent greater than the initial value. The constriction narrowed at Bedrock Canyon because eroded sediment was redeposited on the downstream side of the debris fan across from the island in the center of the rapid (see Stevens, 1990). Surprisingly, the constriction widened at 71.2 Mile despite its history of reworking by larger dam releases in the $1980 \mathrm{~s}$. This widening may reflect changes in sand bars on both sides of the river instead of real change in the debris fan.

The mean surface velocity did not change consistently at the six rapids where velocities were measured (table 7). At Lava Falls Rapid, the velocities of the left and right sides decreased by about half. This velocity decrease is consistent with the sizeable decrease in channel constriction at this site (table 6). At Badger Creek Rapid, 18 Mile riffle, and Lava Canyon Rapid, on the other hand, surface velocities increased (table 7). Because the water-surface fall remained unchanged or decreased slightly in these rapids, we attribute the velocity increases to decreases in bed roughness in the rapid, possibly because of deposition of cobbles and small boulders among larger particles on the bed of the river.

The water-surface fall through eight of ten rapids was altered by the controlled flood (table 8 ). The largest changes were in Tanner and Lava Falls rapids, where the water-surface fall decreased by $0.3 \mathrm{~m}$ and increased by $0.2 \mathrm{~m}$, respectively. The locations of changes in water-surface profile varied among the rapids and debris fans (fig. 13). At Tanner Rapid, most of the change occurred at the top of the rapid, whereas at Lava Falls, the largest changes occurred at the bottom of the rapid. The change at Lava Falls Rapid probably is related to the partial removal of a small, submerged debris bar that had formed downstream from the rapid after the 1995 debris flow (Webb and Melis, 1995; Webb and others, 1996, fig. 13).

Changes in the percent constriction reflect complex interactions between velocity, the stagedischarge relation, the width of the rapid, and changes in bed roughness. Stream power is one measure that reflects all of these variables. Unit stream power decreased at 9 of 10 debris fans by 1 to 16 percent. The one exception is the debris fan at Tanner Canyon, where the channel width decreased by 3 meters. 

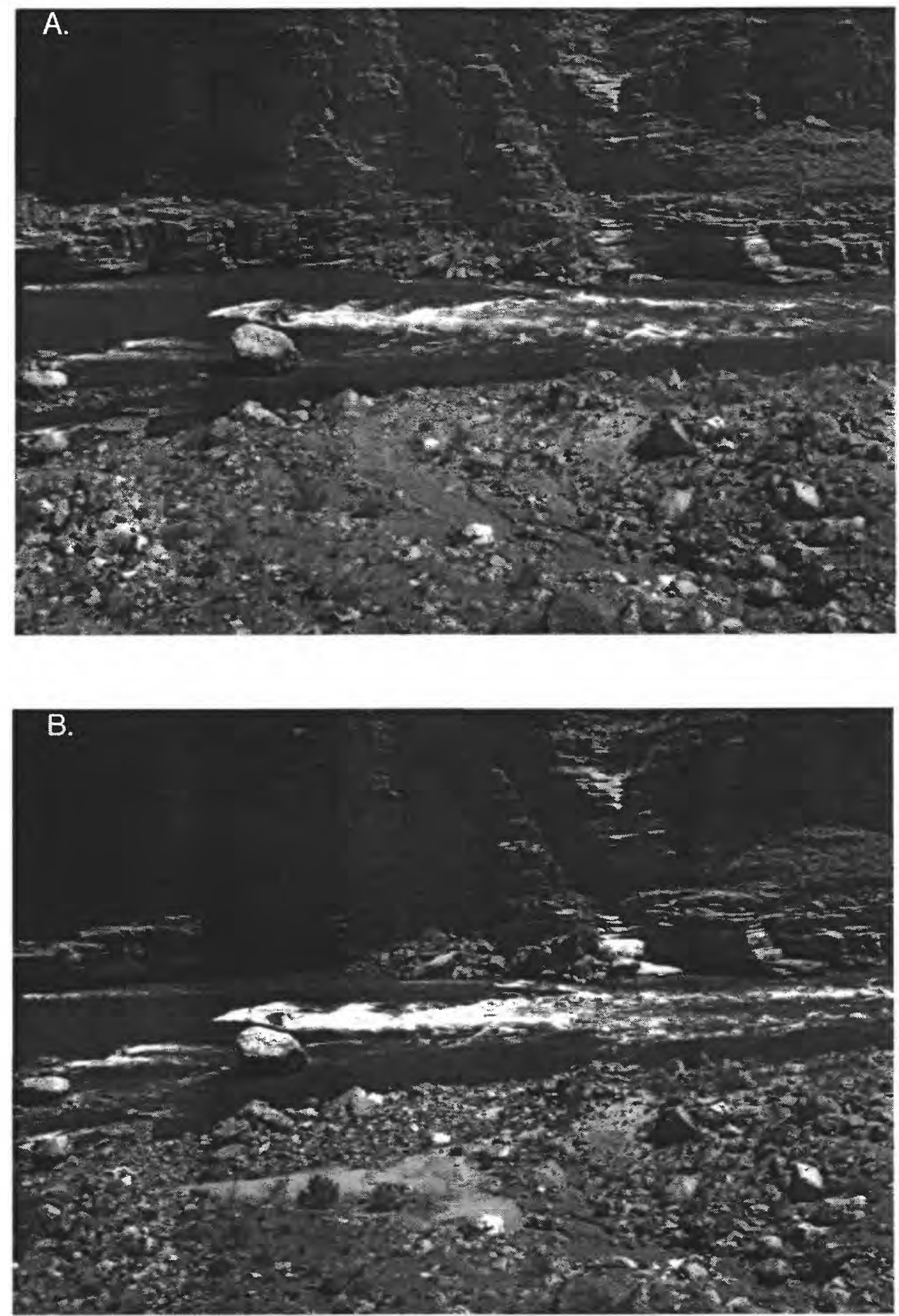

Figure 9. Photographs that document reworking of the debris fan at 62.5 Mile. A, (March 1996). A debris flow in 1990 deposited the large boulders in the river shown at left, including the massive boulder in the center of the view (Melis and others, 1994). The discharge is about $246 \mathrm{~m}^{3} / \mathrm{s}$. B, (April 1996). The 1996 controlled flood rotated several of the large boulders and increased the width of the reworking zone by $10 \mathrm{~m}$. A small sandbar was deposited upslope of the reworked zone. The discharge is about $244 \mathrm{~m}^{3} / \mathrm{s}$. 

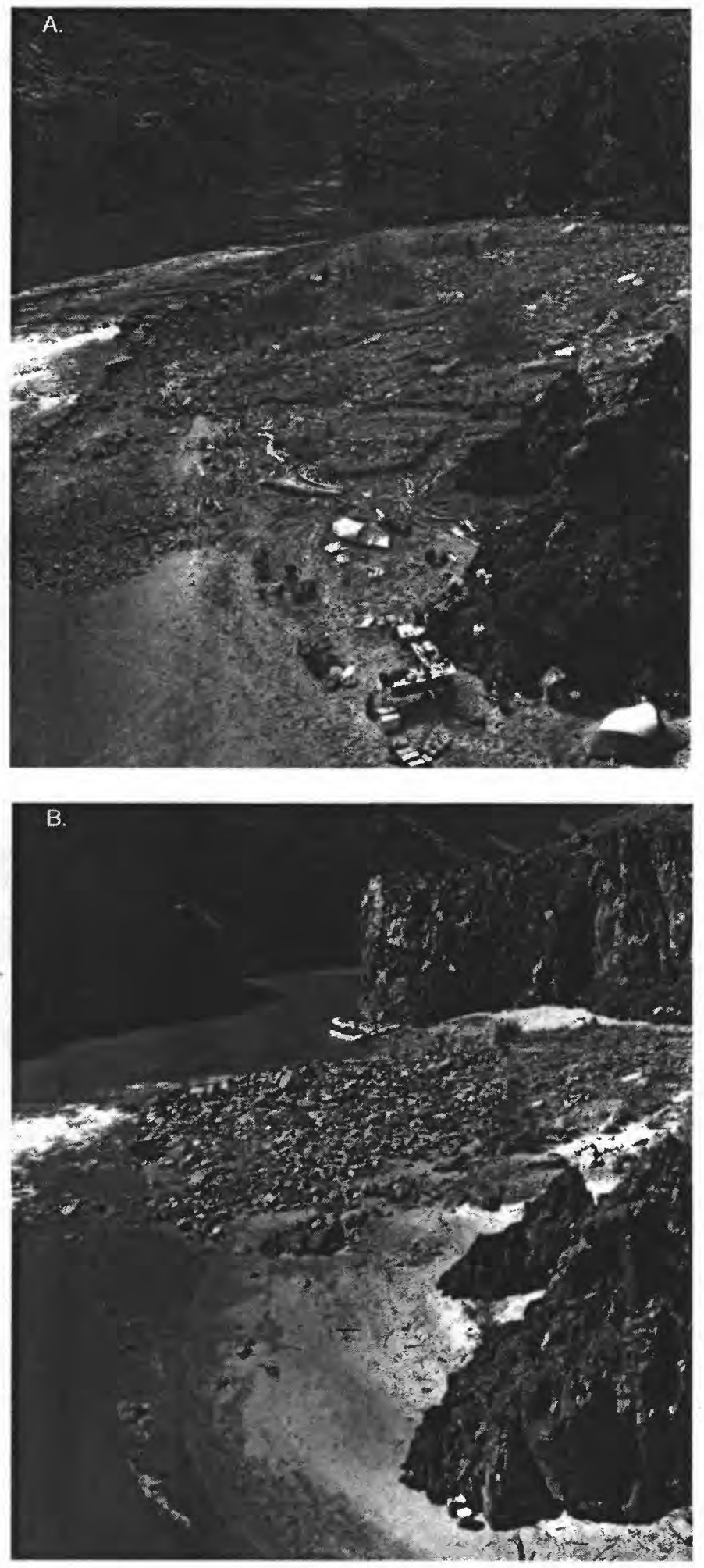

Figure 10. Photographs that document reworking of the debris fan at 127.6 Mile. $A$, (March 1996). The combination of a debris flow in 1989 and small streamflow floods, the last of which occurred in 1993, aggraded the debris fan at 127.6 Mile, covering an existing sandbar. The large volume of driftwood was deposited following the 1993 flood in the Little Colorado River. The discharge is about $245 \mathrm{~m}^{3} / \mathrm{s}$. B, (April 1996). Reworking by the 1996 controlled flood reduced the area and volume of the debris fan by $300 \mathrm{~m}^{2}$ and $1,600 \mathrm{~m}^{3}$, respectively. The width of the reworked zone increased 14 $\mathrm{m}$, and the particle-size distribution on the distal margin of the debris fan coarsened from $\mathrm{D}_{85}=440 \mathrm{~mm}$ before the flood to $D_{85}=620 \mathrm{~mm}$ afterwards. The discharge is about $248 \mathrm{~m}^{3} / \mathrm{s}$. 

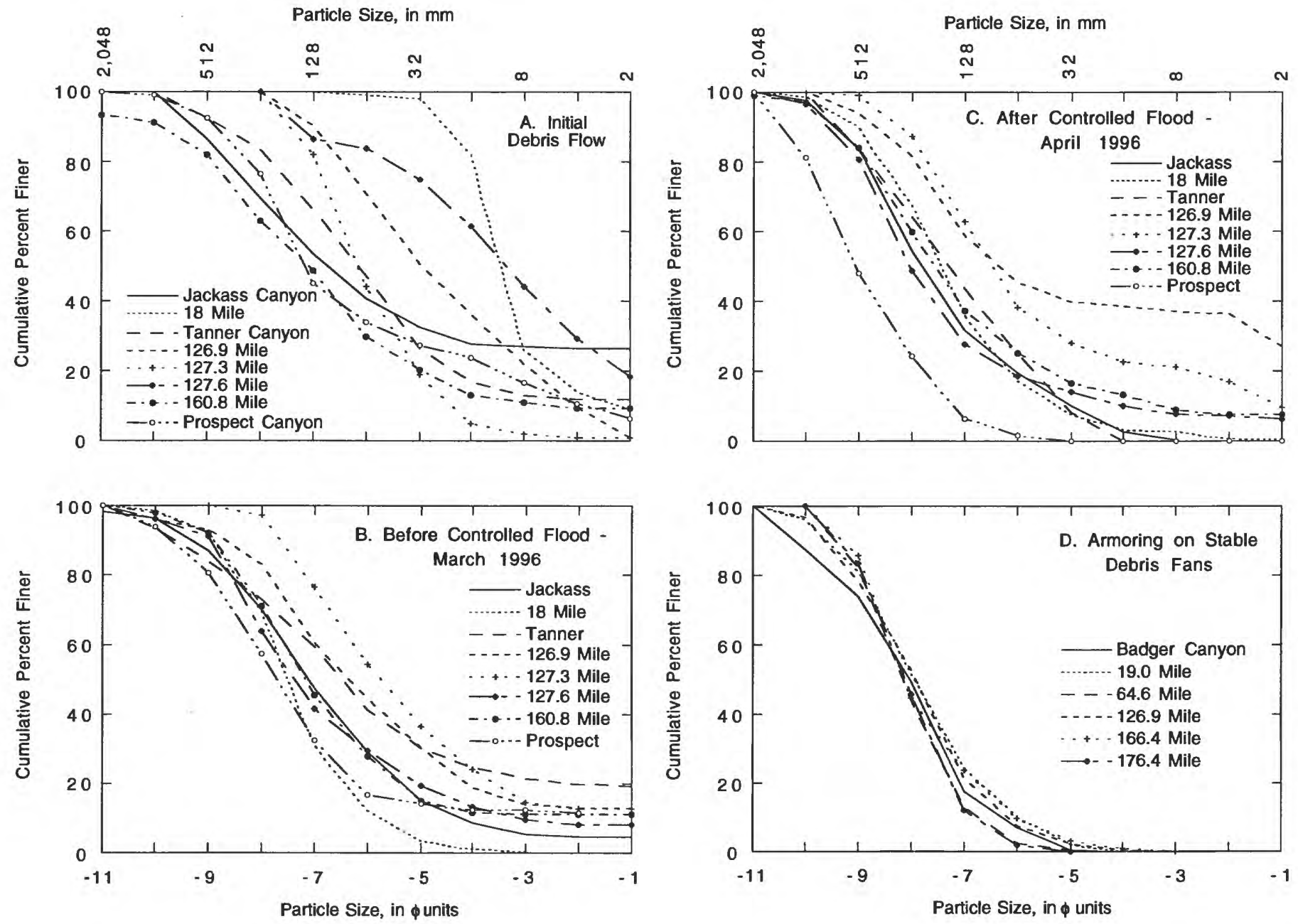

Figure 11. Particle-size distributions reflecting the variability of reworking on 8 recently-aggraded and pre-dam reworked debris fans in Grand Canyon. $A$, Initial particle-size distributions for distal fan margins following debris flows. $B$, Intermediate particle-size distributions reflecting river reworking at distal fan margins in March 1996, before the controlled flood. $C$, Intermediate particle-size distributions reflecting river reworking at distal fan margins in April 1996 after reworking by the controlled flood. $D$, Particle-size distributions for debris fans near study sites where debris flows have not occurred in over a century. These debris fans were reworked by high magnitude, predam floods and approach the endpoint armoring of stable debris fans. 

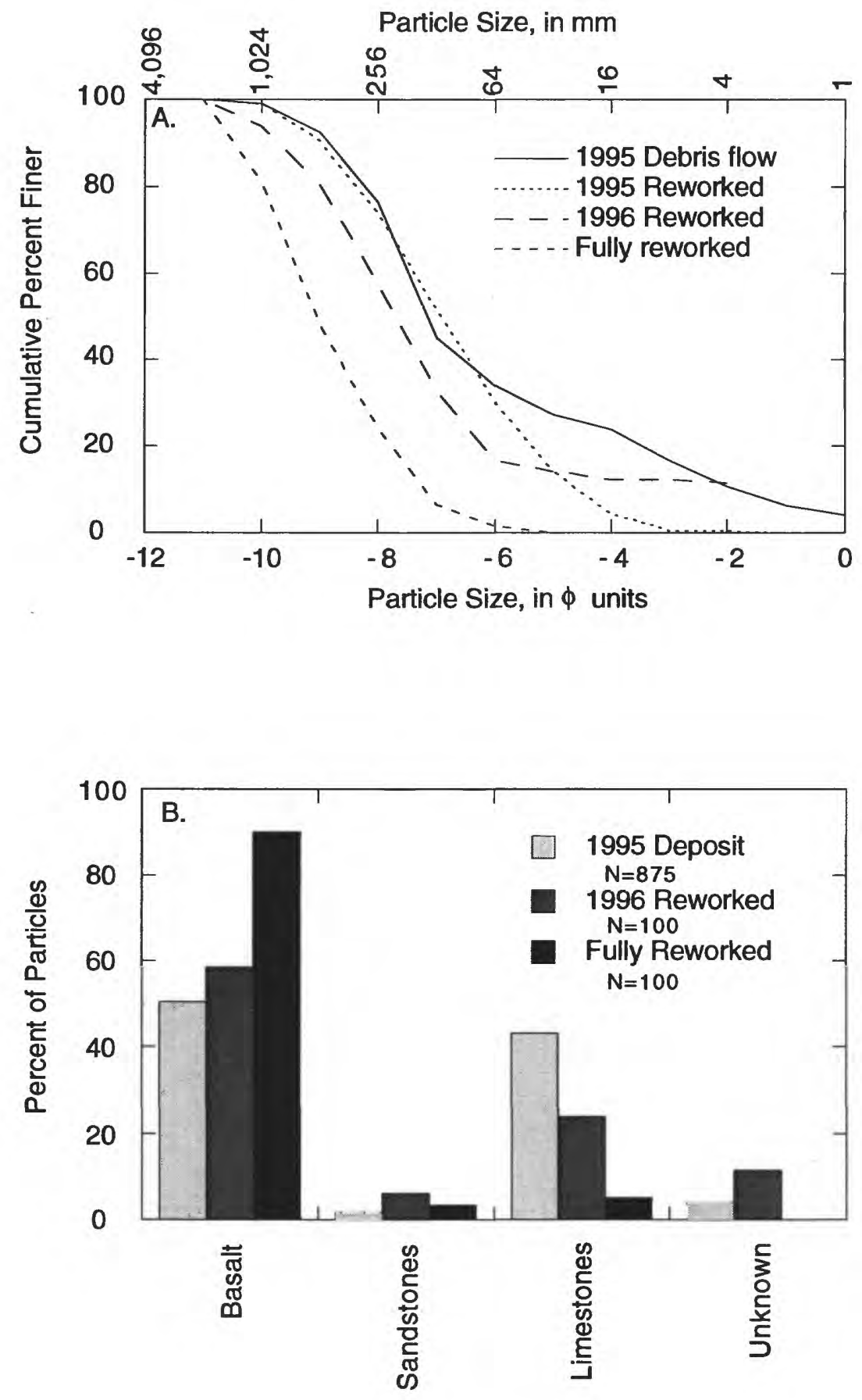

Figure 12. Effects of the 1996 controlled flood on particles on the distal margin of the Prospect Canyon debris fan at Lava Falls Rapid (modified from Webb and others, 1996), reworked by the 1983 flood. $A$, Particle-size distributions of the distal margins of the debris fan. The "fully reworked" curve is for the debris fan before the 1995 debris flow (Webb and others, 1996). B, Lithologies of particles at various stages of reworking. 
Table 5. Changes in the width of the reworked zone on the distal margin of debris fans reworked and percent of the debris fan that was inundated by the 1996 controlled flood in Grand Canyon

\begin{tabular}{ccccc}
\hline Debris fan & $\begin{array}{c}\text { Pre-flood } \\
\text { width }(\mathrm{m})\end{array}$ & $\begin{array}{c}\text { Post-flood } \\
\text { width }(\mathrm{m})\end{array}$ & $\begin{array}{c}\text { Change } \\
(\%)\end{array}$ & $\begin{array}{c}\text { Area of fan } \\
\text { inundated }(\%)\end{array}$ \\
\hline Jackass Canyon $^{*}$ & 23 & 14 & -39 & 100 \\
18 Mile & 7 & 15 & 114 & 79 \\
62.5 Mile & 3 & 13 & 333 & $\mathrm{~nm}$ \\
63.3 Mile $^{\dagger}$ & 7 & 9 & 29 & $\mathrm{~nm}$ \\
Palisades Creek $^{\dagger}$ & 11 & 11 & 0 & $\mathrm{~nm}$ \\
Tanner Canyon $^{\#}$ & 5 & 8 & 60 & 52 \\
Cardenas Creek $^{\#}$ & 10 & 16 & 60 & $\mathrm{~nm}$ \\
71.2 Mile & 8 & 9 & 13 & $\mathrm{~nm}$ \\
72.1 Mile & 10 & 14 & 40 & $\mathrm{~nm}$ \\
Crystal Creek $^{\S}$ & 3 & 33 & 1000 & $\mathrm{~nm}$ \\
126.9 Mile & 6 & 10 & 67 & 66 \\
127.3 Mile & 7 & 7 & 0 & 69 \\
127.6 Mile & 10 & 24 & 140 & 68 \\
Specter Chasm & 5 & 9 & 80 & $\mathrm{~nm}$ \\
Bedrock Canyon $_{157.6 \text { Mile }}^{160.8 \text { Mile }}$ & 8 & 12 & 50 & $\mathrm{~nm}$ \\
Prospect Canyon & & 12 & 140 & 100 \\
\hline
\end{tabular}

The reworked zone in this case is defined as the width of the debris fan between the 277 and $1,320 \mathrm{~m}^{3} / \mathrm{s} \mathrm{stages.} \mathrm{Except} \mathrm{as} \mathrm{noted,} \mathrm{all} \mathrm{widths} \mathrm{of} \mathrm{the}$ reworked zone are along the debris fan adjacent to the rapid.

$\mathrm{nm}$, not measured.

* Only the reworked width of the 1994 deposition (Melis and others, 1994).

† Only the reworked width of the 1990 deposition (Melis and others, 1994).

\# Only the reworked width of the 1993 deposition (Melis and others, 1994).

$\S$ Only the reworked width of the 1995 deposition (Webb and others, 1996).

Table 6. Changes in percent constrictions $\left(C_{w}\right)$ of debris fans reworked by the 1996 controlled flood in Grand Canyon

\begin{tabular}{cccc}
\hline $\begin{array}{c}\text { Debris fan } \\
\text { (rapid) }\end{array}$ & $\begin{array}{c}\text { Pre-flood } \\
\mathbf{C}_{\mathbf{w}}(\%)\end{array}$ & $\begin{array}{c}\text { Post-flood } \\
\mathbf{C}_{\mathbf{w}}(\%)\end{array}$ & $\begin{array}{c}\text { Change } \\
(\%)\end{array}$ \\
\hline Jackass Canyon & 22 & 20 & -10 \\
18 Mile & 54 & 50 & -7 \\
62.5 Mile & 55 & 45 & -18 \\
63.3 Mile & 70 & 69 & -1 \\
Palisades Creek & 55 & 56 & +2 \\
Tanner Canyon & 31 & 33 & +6 \\
Cardenas Creek & 56 & 55 & -2 \\
71.2 Mile & 13 & 12 & -8 \\
72.1 Mile & 10 & 10 & 0 \\
Crystal Creek & 55 & 52 & -5 \\
126.9 Mile & 54 & 53 & -2 \\
127.3 Mile & 24 & 24 & 0 \\
127.6 Mile & 47 & 42 & -11 \\
Specter Chasm & 32 & 27 & -16 \\
Bedrock Canyon & 64 & 66 & +3 \\
157.6 Mile & 33 & 35 & +6 \\
160.8 Mile & 47 & 48 & +2 \\
Prospect Canyon & 42 & 34 & -19 \\
\hline
\end{tabular}

nd, no data 
Table 7. Velocities measured in rapids before, during, and after the 1996 controlled flood in Grand Canyon

\begin{tabular}{lccccccc}
\hline $\begin{array}{c}\text { Debris fan } \\
\text { (Rapid) }\end{array}$ & $\begin{array}{c}\text { Part } \\
\text { of rapid }\end{array}$ & $\begin{array}{c}\text { BEFORE } \\
\text { (mean } \pm \text { SD) }\end{array}$ & $\begin{array}{c}\text { VELOCITY }(\mathrm{m} / \mathbf{s}) \\
\text { DURING } \\
\text { (mean } \pm \text { SD) }\end{array}$ & $\begin{array}{c}\text { AFTER } \\
\text { (mean } \pm \text { SD) }\end{array}$ & Before & During & After \\
\hline $\begin{array}{l}\text { Jackass Canyon } \\
\text { (Badger Creek) }\end{array}$ & Center & $3.5 \pm 0.1$ & $\mathrm{~nm}$ & $4.0 \pm 0.3$ & 248 & $\mathrm{~nm}$ & 259 \\
18 Mile & Center & $2.7 \pm 0.2$ & $\mathrm{~nm}$ & $3.3 \pm 0.1$ & 248 & $\mathrm{~nm}$ & 230 \\
Palisades Creek & Left & $3.6 \pm 0.1$ & $4.8 \pm 0.3$ & $3.9 \pm 0.1$ & 246 & 1,300 & 244 \\
(Lava Canyon) & & & & & & & \\
Tanner Canyon & Left & $\mathrm{nm}$ & $4.9 \pm 0.5$ & $\mathrm{~nm}$ & $\mathrm{~nm}$ & 1,290 & $\mathrm{~nm}$ \\
(Tanner) & Center & $4.3 \pm 0.1$ & $5.7 \pm 0.2$ & $4.3 \pm 0.1$ & 246 & 1,290 & 243 \\
127.6 Mile & Center & $3.0 \pm 0.2$ & $\mathrm{~nm}$ & $2.8 \pm 0.1$ & 245 & $\mathrm{~nm}$ & 248 \\
Prospect Canyon & Left & $3.1 \pm 0.3$ & $6.6 \pm 0.4$ & $1.7 \pm 0.2$ & 254 & 1,270 & 246 \\
(Lava Falls) & Center & $\mathrm{nm}$ & $5.1 \pm 0.2$ & $\mathrm{~nm}$ & $\mathrm{~nm}$ & 1,270 & $\mathrm{~nm}$ \\
& Right & $4.6 \pm 0.2$ & $5.1 \pm 0.1$ & $2.3 \pm 0.3$ & 254 & 1,270 & 246 \\
\hline
\end{tabular}

$\mathrm{SD}$, standard deviation. $\mathrm{nm}$, not measured

Table 8. Changes in water-surface profiles and stream power around selected debris fans at a discharge of 230$254 \mathrm{~m}^{3} / \mathrm{s}$ before and after the 1996 controlled flood in Grand Canyon

\begin{tabular}{|c|c|c|c|c|c|c|c|c|c|c|c|}
\hline \multirow[b]{2}{*}{$\begin{array}{l}\text { Debris fan } \\
\text { (Rapid) }\end{array}$} & \multicolumn{3}{|c|}{ WATER-SURFACE FALL } & \multirow{2}{*}{$\begin{array}{c}\text { LENGTH } \\
\text { OF RAPID } \\
\text { (m) }\end{array}$} & \multicolumn{2}{|c|}{$\begin{array}{l}\text { WATER-SURFACE } \\
\text { SLOPE }\end{array}$} & \multicolumn{2}{|c|}{$\begin{array}{l}\text { WIDTH } \\
\text { OF RAPID }\end{array}$} & \multicolumn{3}{|c|}{ UNIT STREAM POWER } \\
\hline & $\begin{array}{l}\text { Before } \\
\text { flood } \\
(\mathrm{m})\end{array}$ & $\begin{array}{l}\text { After } \\
\text { flood } \\
\text { (m) }\end{array}$ & $\begin{array}{l}\text { Differ- } \\
\text { ence } \\
\text { (m) }\end{array}$ & & $\begin{array}{c}\text { Before } \\
\text { flood } \\
\text { (m) }\end{array}$ & $\begin{array}{c}\text { After } \\
\text { flood } \\
\text { (m) }\end{array}$ & $\begin{array}{c}\text { Before } \\
\text { flood } \\
\text { (m) }\end{array}$ & $\begin{array}{l}\text { After } \\
\text { flood } \\
\text { (m) }\end{array}$ & $\begin{array}{l}\text { Before } \\
\text { flood } \\
\left(\mathrm{w} / \mathrm{m}^{2}\right)\end{array}$ & $\begin{array}{c}\text { After } \\
\text { flood } \\
\left(\mathrm{w} / \mathrm{m}^{2}\right)\end{array}$ & $\begin{array}{c}\text { Differ- } \\
\text { ence } \\
(\%)\end{array}$ \\
\hline $\begin{array}{c}\text { Jackass Canyon } \\
\text { (Badger Creek) }\end{array}$ & 4.39 & 4.41 & 0.02 & 230 & 0.024 & 0.024 & 59 & 63 & 940 & 890 & -5 \\
\hline 18 Mile & 0.94 & 0.99 & 0.05 & 75 & 0.014 & 0.014 & 38 & 38 & 840 & 830 & -1 \\
\hline $\begin{array}{r}\text { Palisades Creek } \\
\text { (Lava Canyon) }\end{array}$ & 1.75 & 1.63 & -0.12 & 115 & 0.021 & 0.019 & 55 & 54 & 880 & 800 & -9 \\
\hline $\begin{array}{l}\text { Tanner Canyon } \\
\text { (Tanner) }\end{array}$ & 2.23 & 1.96 & -0.27 & 145 & 0.017 & 0.017 & 107 & 104 & 360 & 370 & +3 \\
\hline 126.9 Mile $^{*}$ & 0.57 & 0.57 & 0.00 & 110 & 0.014 & 0.015 & 35 & 35 & 1120 & 1040 & -7 \\
\hline 127.3 Mile & 0.16 & 0.16 & 0.00 & 50 & 0.005 & 0.004 & 38 & 38 & 310 & 260 & -16 \\
\hline 127.6 Mile & 0.95 & 1.01 & 0.06 & 70 & 0.024 & 0.024 & 29 & 32 & 2040 & 1820 & -11 \\
\hline 157.6 Mile & 0.98 & 1.01 & 0.03 & 60 & 0.016 & 0.016 & 35 & 36 & 1090 & 1070 & -2 \\
\hline 160.8 Mile & 1.37 & 1.32 & -0.05 & 75 & 0.018 & 0.017 & 36 & 37 & 1190 & 1110 & -7 \\
\hline $\begin{array}{l}\text { Prospect Canyon } \\
\text { (Lava Falls) }\end{array}$ & 3.12 & 3.42 & 0.21 & 85 & 0.038 & 0.041 & 40 & 46 & 2270 & 2150 & -5 \\
\hline
\end{tabular}



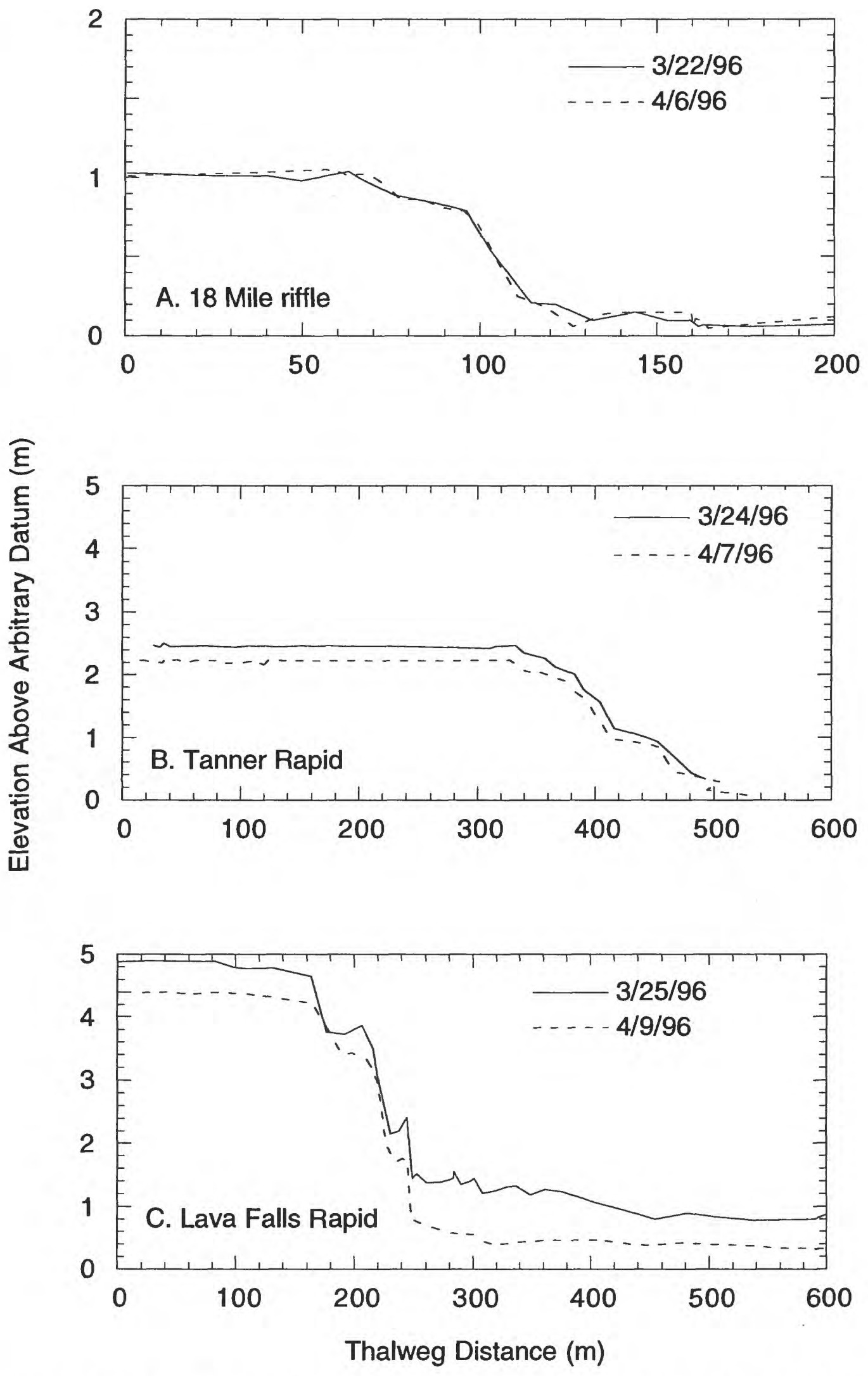

Figure 13. Water-surface profiles through selected rapids showing the effects of the controlled flood of 1996 . All watersurface profiles were surveyed at discharges between 230 and $248 \mathrm{~m}^{3} / \mathrm{s}$. A, 18 Mile riffle, left side. B, Tanner Rapid, right side. C, Lava Falls Rapid, right side. 

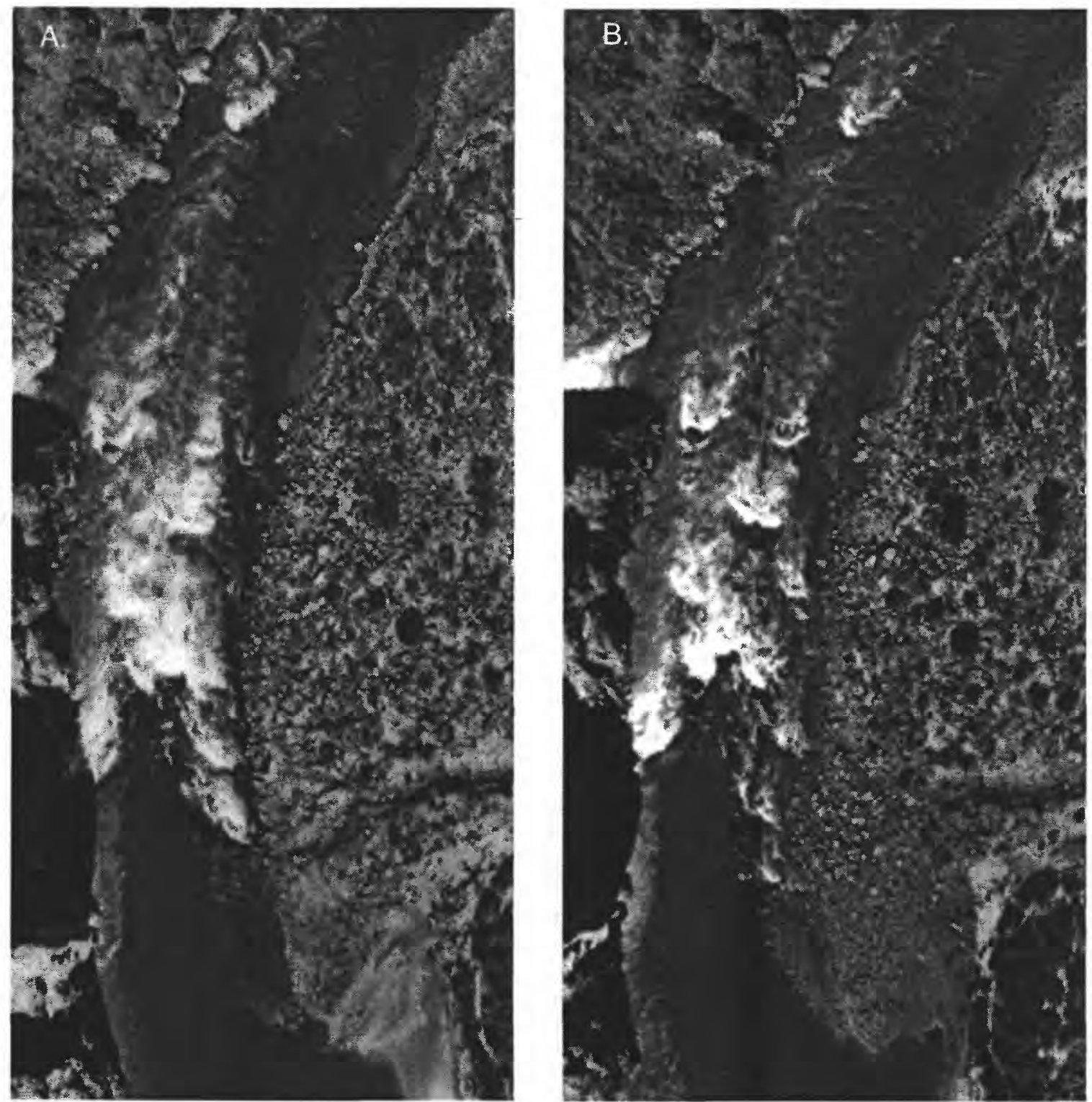

Figure 14. Aerial photographs that document changes of the debris fan at Crystal Rapid. $A$, (March 24, 1996). Crystal Rapid was constricted by a 1966 debris flow from Crystal Creek and reworked by the 1983 flood (Kieffer, 1985). In March 1995, floods in Crystal Creek pushed large boulders from the debris fan into the right side of the rapid, changing the hydraulics significantly. The strong waves on the upstream, right side of the rapid were difficult to break through, and boats were propelled into large waves in the center of the rapid. The discharge is about $254 \mathrm{~m}^{3} / \mathrm{s}$. B, (April 9, 1996). The right lateral waves on the upstream part of the rapid are obviously less severe, as is the wave at the top center of Crystal Rapid. Reworking during the rising limb of the 1996 controlled flood removed only $100 \mathrm{~m}^{2}$ of the edge of the debris fan, decreasing the constriction from 55 to 52 percent. The discharge is about $246 \mathrm{~m}^{3} / \mathrm{s}$.

\section{Decreased Severity of Crystal Rapid}

The navigational severity of Crystal Rapid, the second largest rapid in Grand Canyon (Stevens, 1990; Webb, 1996), significantly decreased during the 1996 controlled flood. On the basis of slight changes in area and percent constriction (tables 2 and 6), one might conclude that Crystal Rapid changed very little. However, several large boulders in the right side of the rapid were removed, decreasing the intensity of the lateral waves on the right side (fig. 14) and reducing the navigational severity of the rapid. The 1996 controlled flood caused significant changes to the two largest rapids in Grand Canyon, although in the case of Lava Falls Rapid, the changes were easily detected with our measurements. 
Table 9. Change in sandbar area on the upstream and downstream margins of debris fans reworked by the 1996 controlled flood in Grand Canyon

\begin{tabular}{|c|c|c|c|c|c|c|}
\hline \multirow[b]{2}{*}{ Debris fan } & \multicolumn{3}{|c|}{ UPPER POOL SANDBAR } & \multicolumn{3}{|c|}{ SEPARATION SANDBAR } \\
\hline & $\begin{array}{l}\text { Pre-flood } \\
\left(\mathrm{m}^{2}\right)\end{array}$ & $\begin{array}{c}\text { Post-flood } \\
\left(\mathrm{m}^{2}\right)\end{array}$ & $\begin{array}{l}\text { Change } \\
\text { (\%) }\end{array}$ & $\begin{array}{c}\text { Pre-flood } \\
\left(\mathrm{m}^{2}\right)\end{array}$ & $\begin{array}{l}\text { Post-flood } \\
\left(\mathrm{m}^{2}\right)\end{array}$ & $\begin{array}{c}\text { Change } \\
(\%)\end{array}$ \\
\hline Jackass Canyon & 0 & 0 & 0 & 2,600 & 2,900 & +12 \\
\hline 18 Mile & 700 & 600 & -14 & 0 & 1,000 & na \\
\hline 62.5 Mile & 0 & 0 & 0 & 200 & 0 & -100 \\
\hline 63.3 Mile & 0 & 0 & 0 & 0 & 300 & na \\
\hline Palisades Canyon & 0 & 200 & na & 200 & 1,200 & +500 \\
\hline Tanner Canyon & 0 & 0 & 0 & 1,100 & 1,100 & 0 \\
\hline Cardenas Creek & $\mathrm{nm}$ & $\mathrm{nm}$ & $\mathrm{nm}$ & 300 & 300 & 0 \\
\hline 71.2 Mile & 100 & 200 & +100 & 500 & 1,400 & +180 \\
\hline 72.1 Mile & 0 & 0 & 0 & 4,600 & 1,600 & -65 \\
\hline Crystal Creek & 400 & 300 & -25 & 700 & 700 & 0 \\
\hline 126.9 Mile & 100 & 300 & +200 & 100 & 200 & +100 \\
\hline 127.3 Mile & 100 & 0 & -100 & 100 & 100 & 0 \\
\hline 127.6 Mile & 0 & 1,000 & na & 1,000 & 500 & -50 \\
\hline Specter Chasm & 300 & 100 & -67 & 400 & 1,600 & +300 \\
\hline Bedrock Canyon & 1,000 & 800 & -20 & 0 & 400 & na \\
\hline 157.6 Mile & 100 & 100 & 0 & 200 & 0 & -100 \\
\hline 160.8 Mile & 100 & 0 & -100 & 1,200 & 1,600 & 33 \\
\hline Prospect Canyon & 0 & 0 & 0 & 700 & 1,000 & 43 \\
\hline
\end{tabular}

na, not applicable; nm, not measured.

\section{Changes in Sandbars Associated With Aggraded Debris Fans}

The areas of two types of sandbars were measured before and after the controlled flood at discharges of 230 to $254 \mathrm{~m}^{3} / \mathrm{s}$ using image processing. Changes in area following the controlled flood did not follow a set pattern. Equal numbers of sandbars on the upstream side of debris fans, termed "upper-pool deposits" by Schmidt and Graf (1990), increased in area, decreased in area, or remained constant (table 9). In contrast, most (ten) separation bars, on the downstream side of debris fans, increased in area, while only a few (four) decreased in area and four remained constant (table 9). At many debris fans, particularly Specter Chasm and Bedrock Canyon (river miles 129.0 and 130.0, respectively), the separation bars increased dramatically, but at other sites, particularly at $\mathbf{1 5 7 . 6}$ Mile, the sandbar (also known as "First Chance Camp") was completely removed. Overall, there was no significant relation between decrease in fan area and change in sandbar area (either positive or negative) at the 18 sites we monitored.

\section{Transport of Marked Particles}

The 1996 controlled flood removed large boulders from some debris fans, but did not noticeably shift the larger particles on other fans. The number of marked cobbles and boulders that were transported downstream varied among 6 debris fans (figs. 15 and 16). Fewer large particles were transported from previously-reworked debris fans than at recently aggraded fans where debrisflow matrix remained a major component of the deposit.

At Palisades Creek, 94 percent of the marked cobbles placed on the debris fan before the flood were removed and transported downstream (fig. 16, table 10). Small boulders also were moved, but most remained on the debris fan. At 127.6 Mile, 45 percent of the marked boulders were removed from the debris fan, and we photographically 
Median Particle Diameter, in $\mathrm{mm}$
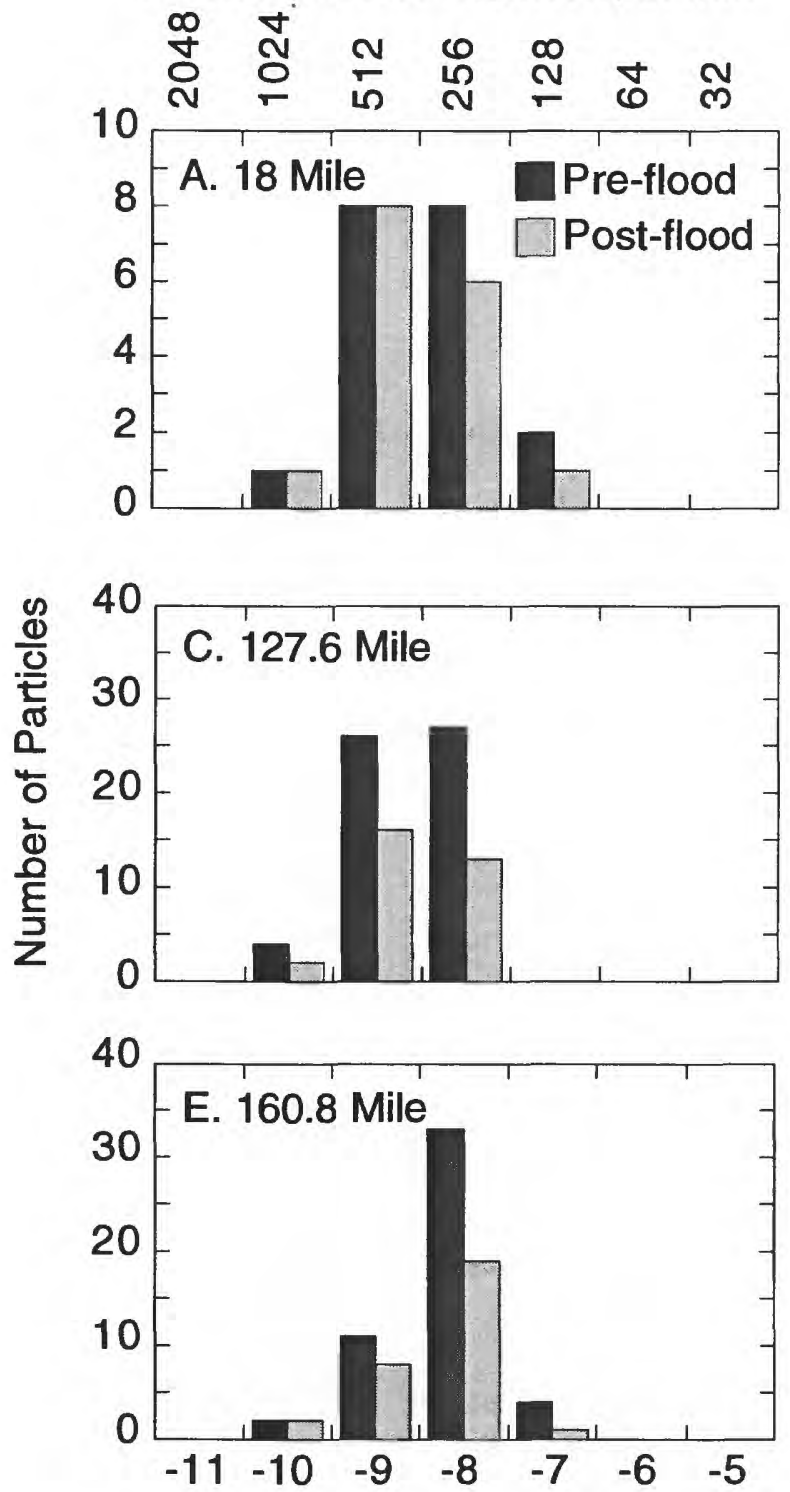

Median Particle Diameter, in $\phi$ Units
Median Particle Diameter, in $\mathrm{mm}$
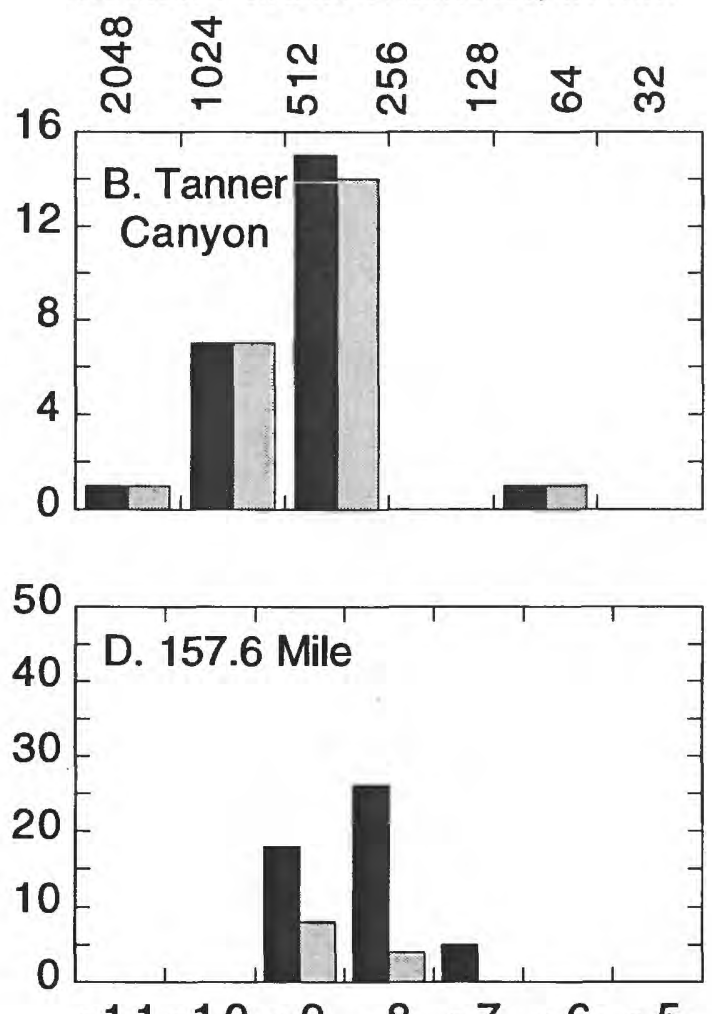

$-11-10-9-8-7-6-5$

Median Particle Diameter, in $\phi$ Units

Figure 15. Transport of marked cobbles and boulders from five aggraded debris fans reworked by the 1996 controlled flood. 


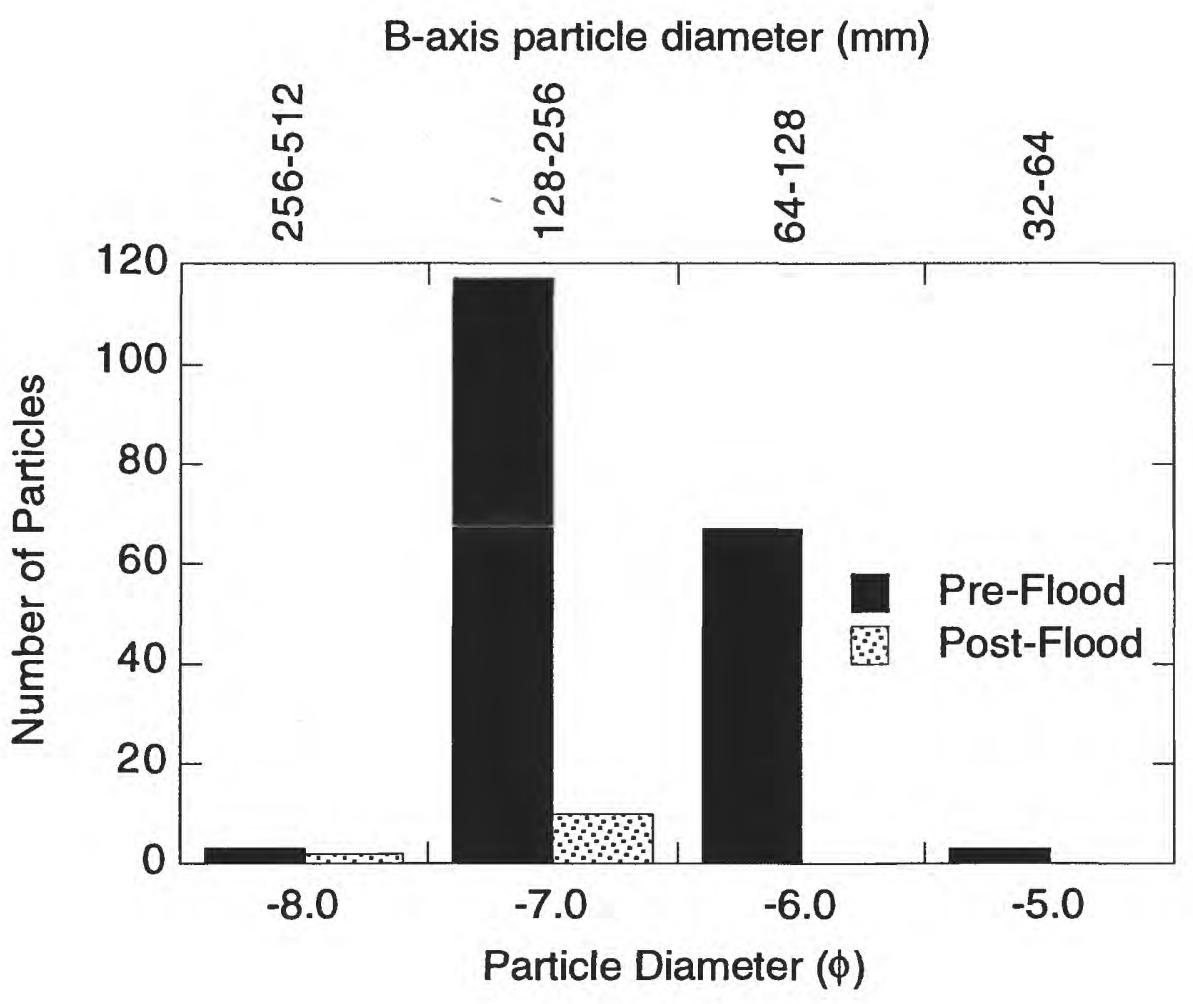

Figure 16.Presence of cobbles and small boulders placed on the Palisades Creek debris fan.

documented transport of one unmarked boulder with an a-axis diameter of more than $2 \mathrm{~m}$. At 157.6 Mile and 160.8 Mile, 76 and 40 percent of the marked particles, respectively, were transported downstream (fig. 15, table 10); boulders with b-axis diameters up to $0.5 \mathrm{~m}$ were removed (fig. 15). In contrast, only 11 percent of the marked particles, with b-axis diameters up to only $0.26 \mathrm{~m}$, were removed from the 18 Mile debris fan. We resurveyed the marked particles after the flood and calculated transport distances on the debris fan (table 10); average travel distances ranged from 0.1 to $32.3 \mathrm{~m}$ for cobbles and 0.1 to $8.2 \mathrm{~m}$ for boulders.

At Lava Falls Rapid, the 10 radio-tagged particles were dislodged at discharges from 470 to $1,020 \mathrm{~m}^{3} / \mathrm{s}$ (table 11) on the rising limb of the flood hydrograph (fig. 8). We relocated 8 of the 10 particles downstream from Lava Falls Rapid after the flood (fig. 17). The smallest particle, a cobble, travelled $420 \mathrm{~m}$ to another debris bar that forms the secondary rapid (Lower Lava). Six relocated particles were deposited in the pool immediately downstream from the main rapid, and one remained in the rapid. The average travel distance for the 8 relocated particles was $230 \mathrm{~m}$ (table 11). The discharge required to actively entrain particles has generally been related to the weight of the particle; and the timing of entrainment is related to the specific flow conditions around the particle and its topographic pocket (Wiberg and Smith, 1987). A theoretical treatment of boulder transport will be the subject of a future report on debris-fan reworking.

Another important factor in large particle transport was the initial position of particles on the debris fan relative to the inundation stage. For some debris fans, such as at Tanner Rapid, many large particles remained above the stage of the controlled flood. Particle position, combined with the previous reworking of the debris fan by lower discharges in August 1994, resulted in only one marked boulder being removed by the 1996 controlled flood (fig. 15b). In contrast, despite the fact that the 18 Mile debris fan was completely inundated, only a few marked cobbles and small boulders were removed (fig. 15a), because the debris fan had been 
Table 10. Movement of marked boulders from five debris fans during the 1996 controlled flood in Grand Canyon

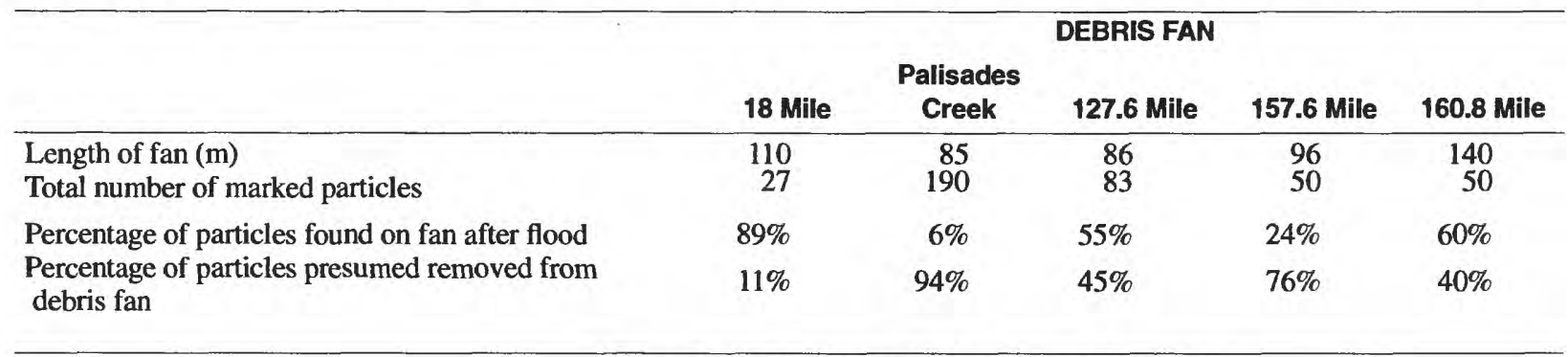

Average travel distance $(\mathrm{m})$ of particles on debris fan by b-axis diameter (number of particles)

\begin{tabular}{ccccccc}
\hline$\phi$ & $\mathrm{mm}$ & \multicolumn{5}{c}{$\begin{array}{c}\text { Distance } \\
(\mathbf{m})\end{array}$} \\
\hline-10 & 1,024 & $0.1(1)$ & $\mathrm{np}$ & $0.3(2)$ & $\mathrm{np}$ & $\mathrm{np}$ \\
-9 & 512 & $2.6(8)$ & $\mathrm{np}$ & $3.9(16)$ & $8.2(8)$ & $3.3(8)$ \\
-8 & 256 & $2.2(6)$ & $32.3(2)$ & $5.1(13)$ & $7.8(4)$ & $3.3(19)$ \\
-7 & 128 & $0.1(1)$ & $3.7(10)$ & $\mathrm{np}$ & $\mathrm{np}$ & $19.5(1)$ \\
\hline
\end{tabular}

$\mathrm{np}$, no particles marked in this size class.

Table 11. Characteristics of radio-tagged particles at Lava Falls Rapid transported during the 1996 controlled flood in Grand Canyon

\begin{tabular}{ccccccccc}
\hline $\begin{array}{c}\text { Particle } \\
\text { number }\end{array}$ & Lithology & $\begin{array}{c}\text { Size } \\
\text { class }\end{array}$ & $\begin{array}{c}\text { b-axis } \\
\text { diameter } \\
(\mathbf{m})\end{array}$ & $\begin{array}{c}\text { Volume } \\
\left(\mathbf{m}^{\mathbf{3}}\right)\end{array}$ & $\begin{array}{c}\text { Weight } \\
(\mathbf{M g})\end{array}$ & $\begin{array}{c}\text { Departure } \\
\text { time }\end{array}$ & $\begin{array}{c}\text { Approximate } \\
\text { discharge } \\
\left(\mathbf{m}^{\mathbf{3}} \mathbf{s}\right)\end{array}$ & $\begin{array}{c}\text { Travel } \\
\text { distance } \\
(\mathbf{m})\end{array}$ \\
\hline 3 & Basalt & Cobble & 0.21 & 0.003 & 0.009 & 1141 & 830 & 420 \\
1 & Sandstone & Cobble & 0.22 & 0.006 & 0.017 & 1102 & 470 & nd \\
4 & Sandstone & Boulder & 0.34 & 0.007 & 0.018 & 1143 & 860 & 230 \\
7 & Basalt & Boulder & 0.28 & 0.011 & 0.029 & 1202 & 940 & 310 \\
2 & Sandstone & Cobble & 0.23 & 0.015 & 0.040 & 1112 & 560 & 110 \\
6 & Sandstone & Boulder & 0.31 & 0.021 & 0.055 & 1214 & 1,020 & 50 \\
8 & Sandstone & Boulder & 0.38 & 0.061 & 0.16 & 1145 & 870 & 250 \\
5 & Basalt & Boulder & 0.49 & 0.065 & 0.18 & 1136 & 780 & nd \\
10 & Sandstone & Boulder & 0.70 & 0.17 & 0.45 & 1212 & 1,010 & 240 \\
9 & Sandstone & Boulder & 0.66 & 0.23 & 0.61 & 1207 & 1,000 & 220 \\
\hline
\end{tabular}

nd, no data because particle could not be located after the flood 


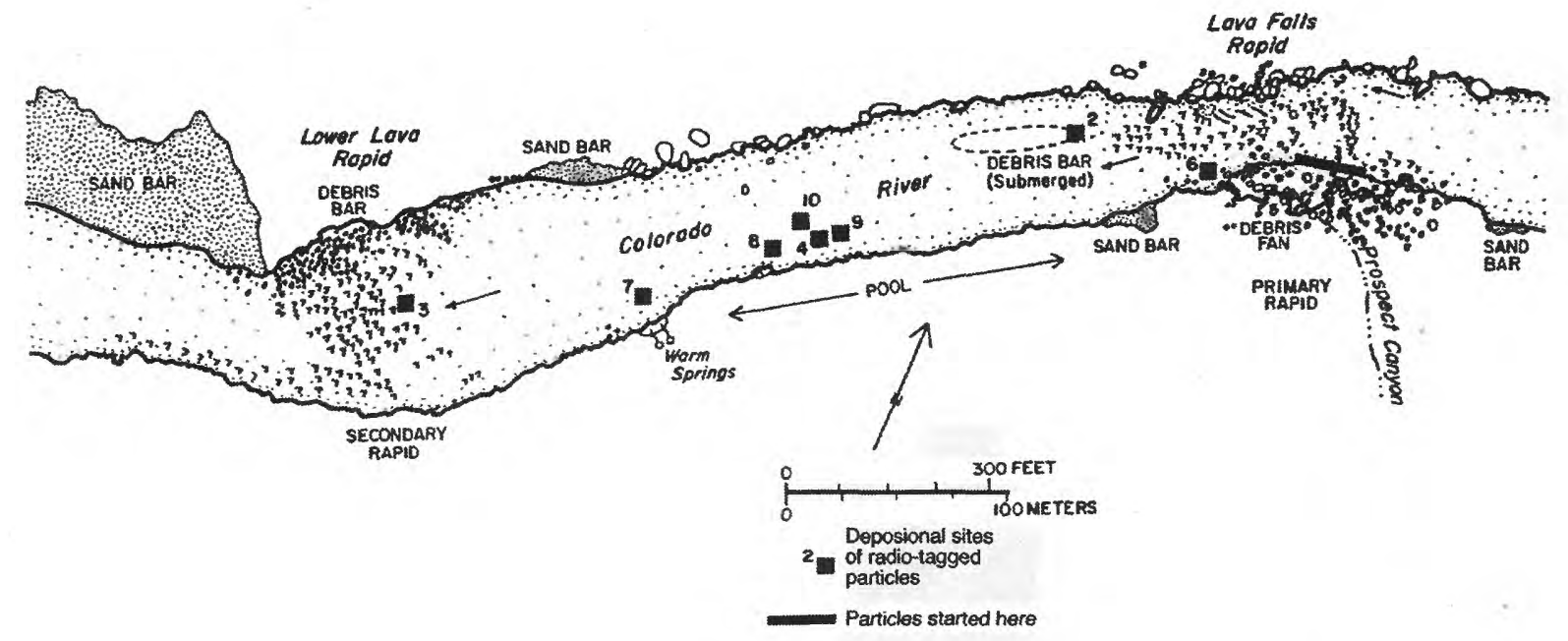

Figure 17. Map showing the depositional sites of 8 radio-tagged cobbles and boulders downstream from Lava Falls Rapids after the 1996 controlled flood.

previously reworked to a limited extent by powerplant releases (Melis and others, 1994).

\section{DISCUSSION AND CONCLUSIONS}

The 1996 controlled flood partially reworked many of the debris fans aggraded since 1983 that we monitored in Grand Canyon. Using several measures of debris-fan reworking, including changes in fan area, fan volume, amount of river constriction, and sediment armoring, we found that the controlled flood caused substantial changes. The peak discharge of $1,370 \mathrm{~m}^{3} / \mathrm{s}$ was a 10 -year flood in the regulated Colorado River, but was smaller than the mean annual flood in the pre-dam river. Our results do not agree with those of Kieffer (1985), who concluded that extremely high discharges are required for significant reworking of debris fans. Instead, our general results are in accord with the observations of Hammack (1994) and Hammack and Wohl (1996), who documented reworking of Warm Springs Rapid on the Yampa River, and Webb and others (1996), who documented the removal of 2 post-dam debris fans at Lava Falls Rapid.
At the Prospect Canyon debris fan (Lava Falls Rapid), we observed significant reworking at rising discharges between 1,000 and $1,200 \mathrm{~m}^{3} / \mathrm{s}$. We observed two types of reworking: (1) failure of unconsolidated debris-flow deposits by lateral erosion, and (2) the entrainment of individual particles from the bed of the river. Most of the reworking of the Prospect Canyon debris fan, which had not been subjected to river discharges greater than $670 \mathrm{~m}^{3} / \mathrm{s}$ before the 1996 controlled flood, resulted from slab failures of unconsolidated debris-flow deposits that were laterally eroded during the flood rise; the debris fan was not overtopped during the flood. These slab failures provided initial motion for large particles at discharges less than what would normally be required to entrain these particle sizes from a previously reworked debris fan, such as the fan at Palisades Creek. Other cobbles and boulders, particularly the ones embedded with radio transmitters, were entrained from the bed as individual particles. This type of particle entrainment may in principle be predicted using theoretical analysis (Wiberg and Smith, 1987).

Reworking of the Prospect Canyon debris fan ended after approximately 4 hours when large 


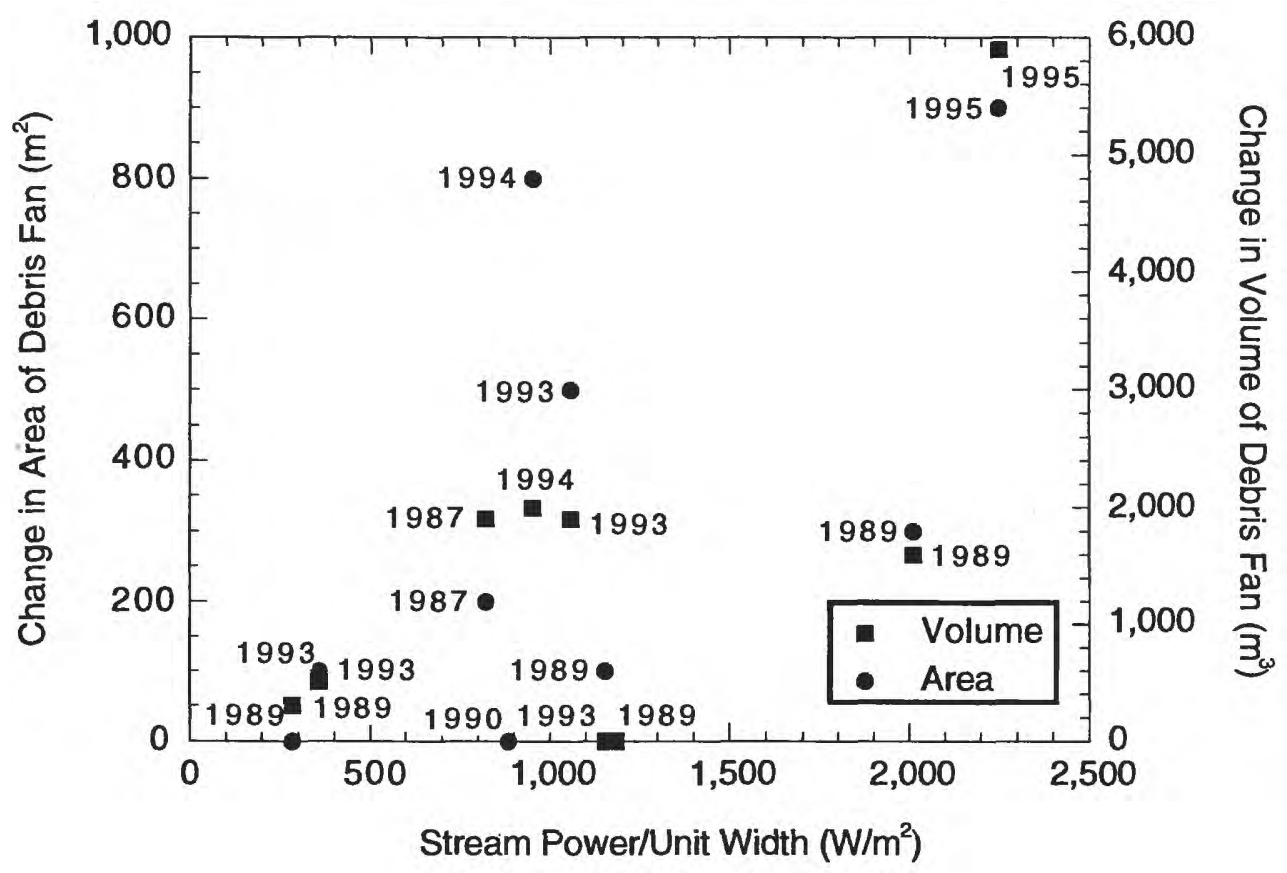

Figure 18. Relations between stream power before the 1996 controlled flood (discharges of $245-254 \mathrm{~m}^{3} / \mathrm{s}$ ), the date of the debris flow that aggraded the debris fan, and changes in area and volume of selected debris fans on the Colorado River in Grand Canyon.

boulders armored the unconsolidated bank, preventing further bank failures. In this case, duration of the flood appeared to be unimportant to reworking, contrary to the conclusions of Hammack and Wohl (1996) at Warm Springs Rapid. The two mechanisms of coarse-particle entrainment documented in this study have important implications for understanding the mobility and evolution of channel features, such as islands and channel bars downstream from large fans and rapids, during both regulated and unregulated flows in the Colorado River (Melis and others, 1994).

We measured significant reductions in the area and volume of recently aggraded debris fans at Prospect Canyon, Jackass Canyon, 157.6 Mile, and 127.6 Mile. The areas of other aggraded debris fans changed only slightly, and we measured no change in area at only 2 debris fans (table 2). Large volumes of sediment were removed from debris fans at Prospect Canyon, Jackass Canyon, 157.6 Mile, 18 Mile, and 127.6 Mile (table 3). Differences in stream power explain many of the differences in area and volume change among the debris fans (fig. 18). Debris fans with high stream power before the controlled flood, such as the Prospect Canyon and 127.6 Mile at (Lava Falls and 127.6 Mile rapids), had large changes in area and volume, whereas sites with low stream power, such as at Tanner Canyon and the aggraded fans at 126.9 Mile and 127.3 Mile, changed relatively little (tables 2,3 , and 8 ). The fan at Mile 160.8 lost a large volume of fine sediment from between boulders, but we were not able to document this type of change with ground surveys. Recent aggradation increases the amount of reworking despite lower stream power (fig. 18). This effect is evident at the Jackass Canyon debris fan, aggraded in 1994, where moderate stream power markedly decreased its area and volume. In contrast, the percent change in unit streampower at each fan following the flood was not a sensitive indicator of the degree of reworking (table 8).

The constrictions at many rapids, particularly 62.5 Mile and Lava Falls Rapid, widened considerably, whereas other constrictions changed only slightly due to the stability of boulders at the distal edges of older fans (table 6, fig. 19a). Initial and reworked constrictions for the debris fans reported here fall within the range of constrictions measured throughout the river system at 

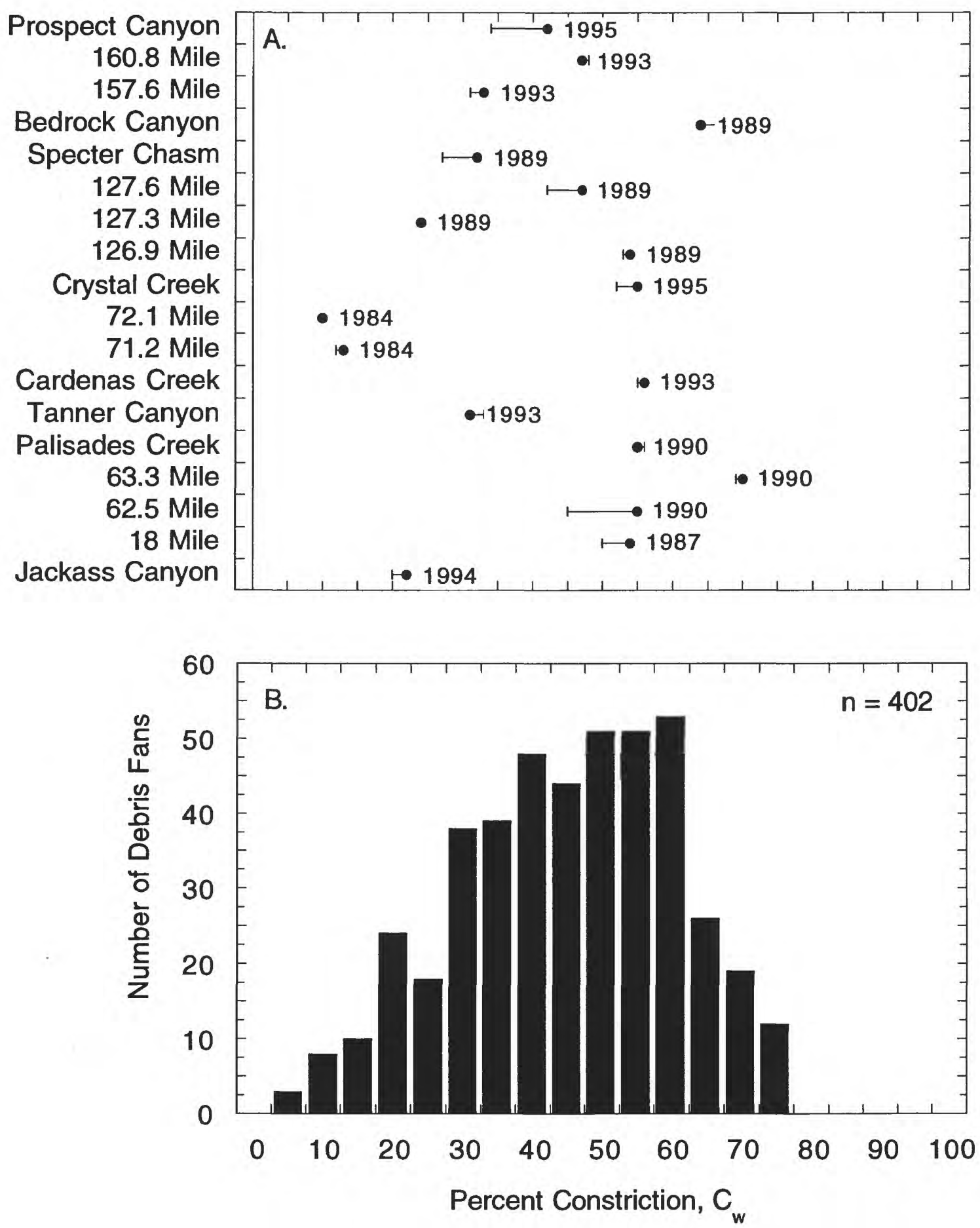

Figure 19. Percent constriction of the Colorado River by debris fans in Grand Canyon. $A$, Changes in aggraded debris fans caused by the 1996 controlled flood. Solid circle, percentage of the channel constricted before the flood. Vertical bar, percentage of the channel constricted after the flood. B, Percent constrictions $\left(C_{w}\right)$ for 144 debris fans between Lees Ferry and Diamond Creek measured from March 1996 aerial photographs taken at discharges ranging from 231$258 \mathrm{~m}^{3} / \mathrm{s}$ (T.S. Melis, unpublished data) 
confluences where fans are present (fig. 19). Changes in percent channel constriction, which is a function of debris-fan area, water-surface fall, and the stage-discharge relation, do not appear to be related to the elapsed time between the most-recent debris flow and the controlled flood. For some debris fans, we measured relatively small changes in percent constrictions, despite the fact that large particles were removed from the fan surface. Based on the amount of reworking by the controlled flood, we conclude that the constriction ratio, which has been used previously to depict the reworking status of rapids (Kieffer, 1985, 1987, 1990), is not a particularly sensitive measure of changes in debris fans and rapids caused by relatively small floods.

Because of reworking by the 1996 controlled flood, navigation of Lava Falls Rapid is essentially the same as it was before the 1995 debris flow (Webb and others, 1996). Velocities at about 250 $\mathrm{m}^{3} / \mathrm{s}$ on the left and right sides of the rapids decreased by half as a result of the controlled flood (table 7). Although the total water-surface fall through Lava Falls Rapid increased by $0.3 \mathrm{~m}$ (table 8 , fig. 13), the stage-discharge relation at the top of the rapid decreased by $0.4 \mathrm{~m}$ (fig. 13), causing exposure of several large boulders on the left side at low discharges. At Crystal Rapid, removal of only a few key boulders decreased the navigational severity of the rapid despite only small changes in the debris fan. Velocities in other rapids increased. At Jackass Canyon (Badger Creek Rapid), the increase probably resulted from partial removal of the aggraded debris fan, which had constricted the middle part of the rapid in 1994, decreasing the velocity at the head of the rapid. Increases in the velocity at 18 Mile were probably caused by deposition of cobbles and boulders among the larger particles on the channel bed, decreasing overall bed roughness.

We attribute the relation between amount of reworking, as measured by changes in area and volume, and the elapsed time between the debris flow and the controlled flood to the history of reworking and armoring by lower discharges in the Colorado River. The low-water controls at several debris fans that aggraded before 1993 and that were reworked by the January 1993 flood were unchanged by the controlled flood. We observed that closest-packing imbrication and even suturing (Webb, 1996) had occurred on parts of debris fans that had been submerged for long periods, typically longer than 3 years. For example, the 1993 debris flow that constricted Tanner Rapid (Melis and others, 1994) increased the stage-discharge relation by $1 \mathrm{~m}$ in the pool above the rapid. This change resulted in the increased storage of sand in the upper pool between October 1993 and March 1996. We expected that this condition would be reversed by reworking during the controlled flood, but large boulders deposited by the debris flow that control the elevation of the pool were unchanged by the flood, and the upper-pool elevation was only reduced by $0.25 \mathrm{~m}$ (a $25 \%$ decrease).

Debris fans aggraded after 1993 were more easily reworked. For example, the low-water control added by the 1995 debris flow at Lava Falls was almost completely removed ( 1 boulder remains), but the low-water controls at Bedrock and Specter rapids, created by debris flows in 1989 , remain. As the interval between the aggrading debris flow and the reworking flood increases, a flood will be less effective in clearing out the constriction, and larger peak discharges will be required. If more significant reworking of aggraded debris fans is a desirable characteristic of future deliberate floods in Grand Canyon, the amount of elapsed time since the last debris flow is one of the most significant criteria.

We documented movement of cobbles and boulders, some with diameters as large as $1.5 \mathrm{~m}$, during the 1996 controlled flood. At 4 of 5 debris fans, 40 percent or more of the marked particles were removed from the debris fan (table 10), and others were transported as far as $32 \mathrm{~m}$. As demonstrated with the radio-tagged particles at Lava Falls Rapid, most of the particles were deposited in the pool downstream from the rapid and not on the alternating debris bars farther downstream (fig. 17). The average travel distance of $230 \mathrm{~m}$ demonstrates the effectiveness of discharges as small as $1,300 \mathrm{~m}^{3} / \mathrm{s}$ in rearranging boulders on some debris fans in the Colorado River. These results, and the nearly complete removal of marked particles from the Palisades Creek debris fan, indicate that large cobbles and small boulders can be readily transported from previously reworked debris fans by floods half the size of the pre-dam annual peak discharge. These size classes are mobile at low discharges (relative to pre-dam conditions) in settings where particle-to-particle 
interactions and pocket topography are critical in controlling entrainment.

Because most of the reworking occurred on the rise in the flood hydrograph, we conclude that the 7day duration of the controlled flood was unnecessary for reworking of debris fans. If management of aggraded debris fans is one of the criteria for design of future controlled floods, the duration of such a flood could be much shorter. However, the design discharge of $1,270 \mathrm{~m}^{3} / \mathrm{s}$, which actually was as high as $1,370 \mathrm{~m}^{3} / \mathrm{s}$ in Grand Canyon, could be increased to have a greater effect on reworking debris fans. Although some recently aggraded debris fans such as at Lava Falls Rapid were partially removed by the 1996 controlled flood, others, such as at Tanner Canyon, were not greatly affected because the stage of the flood was not high enough to erode the side of the aggraded fan or overtop it.

Very short-duration and high-magnitude controlled floods would be highly effective in reworking aggraded debris fans. Such a flood could have a discharge as high as $2,800 \mathrm{~m}^{3} / \mathrm{s}$, or twice the discharge of the 1996 controlled flood (less than a 5 -year flood on the unregulated river), but be designed for a duration of only minutes of peak discharge at sites downstream from the Little Colorado River. The recession of the hydrograph of such a flood, which would mimic some of the predam flash floods through Grand Canyon, could be designed to include steady, beach-building discharges. One potential drawback of such a flood may be that boulders deposited in the downstream pool might require more sustained, high discharges to be flushed downstream.

\section{REFERENCES CITED}

Baker, V.R., and Costa, J.E., 1987, Flood power, in Mayer, L. and Nash, D. (editors), Catastrophic Flooding: London, Allen and Unwin, p. 1-21.

Collier, M.P., Webb, R.H., and Andrews, E.D., 1997, Experimental flooding in Grand Canyon: Scientific American, v. 276, p. 82-89.

Garrett, J.M., and Gellenbeck, D.J., 1991, Basin characteristics and streamflow statistics in Arizona as of 1989: U.S. Geological Survey WaterResources Investigations Report 91-4041, 612 p.
Graf, W.L., 1979, Rapids in canyon rivers: Journal of Geology, v. 87, p. 533-551.

Graf, W.L., 1980, The effect of dam closure on downstream rapids: Water Resources Research, v. 16 , p. $129-136$.

Griffiths, P.G., Webb, R.H., and Melis, T.S., 1996, Initiation and frequency of debris flows in Grand Canyon, Arizona: U.S. Geological Survey OpenFile Report 96-491, 35 p.

Hamblin, W.K., and Rigby, J.K., 1968, Guidebook to the Colorado River, Part 1, Lee's Ferry to Phantom Ranch in Grand Canyon National Park: Provo, Utah, Brigham Young University, Geology Studies, v. 15, part 5, $84 \mathrm{p}$.

Hammack, L.A., 1994, Debris-fan formation and rapid modification at Warm Springs Rapid, Yampa River, Colorado [M.S. Thesis]: Fort Collins, Colorado State University, $125 \mathrm{p}$.

Hammack, L., and Wohl, E., 1996, Debris-fan formation and rapid modification at Warm Springs Rapid, Yampa River, Colorado: Journal of Geology, v. 104, p. 729-740.

Howard, A.D., and Dolan, Robert, 1979, Changes in the fluvial deposits of the Colorado River in the Grand Canyon caused by Glen Canyon Dam, in Linn, R.M. (editor), Proceedings of the First Conference on Scientific Research in the National Parks, Volume II, p. 845-851.

Howard, Alan, and Dolan, Robert, 1981, Geomorphology of the Colorado River in Grand Canyon: Journal of Geology, v. 89, p. 269-297.

Kieffer, S.W., 1985, The 1983 hydraulic jump in Crystal Rapid: Implications for river-running and geomorphic evolution in the Grand Canyon: Journal of Geology, v. 93, p. 385-406.

Kieffer, S.W., 1987, The rapids and waves of the Colorado River, Grand Canyon, Arizona: U.S. Geological Survey Open-File Report 87-096, 69 p.

Kieffer, S.W., 1990, Hydraulics and geomorphology of the Colorado River in the Grand Canyon, in Beus, S.S., and Morales, M. (editors), Grand Canyon geology: New York, Oxford University Press, p. 333-383.

Melis, T.S., Webb, R.H., Griffiths, P.G., and Wise, T.J., 1994, Magnitude and frequency data for historic debris flows in Grand Canyon National Park and vicinity, Arizona: U.S. Geological Survey Water Resources Investigations Report 94-4214, 285 p. 
O'Connor, J.E., Ely, L.L., Wohl, E.E., Stevens, L.E., Melis, T.S., Kale, V.S., and Baker, V.R., 1994, A 4,500 year record of large floods on the Colorado River in Grand Canyon, Arizona: Journal of Geology, v. 102, p. 1-9.

Péwé, T.L., 1968, Colorado River guidebook, Lees Ferry to Phantom Ranch: Tempe, Arizona, privately published, $78 \mathrm{p}$.

Schmidt, J.C., 1990, Recirculating flow and sedimentation in the Colorado River in Grand Canyon, Arizona: Journal of Geology, v. 98, p. 709724.

Schmidt, J.C., and Graf, J.B., 1990, Aggradation and degradation of alluvial sand deposits, 1965-1986, Colorado River, Grand Canyon National Park, Arizona: U.S. Geological Survey Professional Paper $1493,74 \mathrm{p}$.

Schmidt, J.C., and Rubin, D.M., 1995, Regulated streamflow, fine-grained deposits, and effective discharge in canyons with abundant debris fans, in Natural and Anthropogenic Influences in Fluvial Geomorphology: Washington, D.C., American Geophysical Union, Geophysical Monograph 89, p. 177-195.

Simmons, G.C., and Gaskill, D.L., 1969, River runner's guide to the canyons of the Green and Colorado Rivers, with emphasis on geologic features, Volume III, Marble Gorge and Grand Canyon: Flagstaff, Arizona, Northland Press, 132 p.

Stevens, L., 1990, The Colorado River in Grand Canyon, A guide: Flagstaff, Arizona, Red Lake Books, 115 p.

U.S. Department of the Interior, 1995, Operation of Glen Canyon Dam, Final environmental impact report: Salt Lake City, Utah, Bureau of Reclamation, Upper Colorado Region, variable page numbers.

U.S. Water Resources Council, 1981, Guidelines for determining flood flow frequency: Hydrology Subcommittee Bulletin 17B, 183 p.

Webb, R.H., 1996, Grand Canyon, a century of change: Tucson, University of Arizona Press, 290 p.

Webb, R.H., and Melis, T.S., 1995, The 1995 debris flow at Lava Falls Rapid: Nature Notes, v. 11, p. 1-4.

Webb, R.H., Pringle, P.T., Reneau, S.L., and Rink, G.R., 1988, Monument Creek debris flow, 1984: Implications for formation of rapids on the Colorado River in Grand Canyon National Park: Geology, v. 16, p. $50-54$.
Webb, R.H., Pringle, P.T., and Rink, G.R., 1989, Debris flows from tributaries of the Colorado River, Grand Canyon National Park, Arizona: U.S. Geological Survey Professional Paper 1492, 39 p.

Webb, R.H., Melis, T.S., and Wise, T.W., 1996, "The great cataract," Effects of late Holocene debris flows on Lava Falls Rapid, Grand Canyon National Park and Hualapai Indian Reservation, Arizona: U.S. Geological Survey Open-file Report 96-460, $96 \mathrm{p}$.

Wegner, D.L., 1991, A brief history of the Glen Canyon Environmental Studies, in Colorado River Ecology and Dam Management, Proceedings of a Symposium, May 24-25, 1990, Santa Fe, New Mexico: Washington, D.C., National Academy Press, p. 226-238.

Wiberg, P.L., and Smith, J.D., 1987, Calculations of the critical shear stress for motion of uniform and heterogeneous sediments: Water Resources Research, v. 23, p. 1471-1480.

Wiele, S.M., 1996, Calculated hydrographs for the Colorado River downstream from Glen Canyon Dam during the experimental release, March 22 April 8, 1996: U.S. Geological Survey Fact Sheet FS-083-96, 2 p.

Wiele, S.M., and Smith, J.D., 1996, A reach-averaged model of diurnal discharge wave propagation down the Colorado River through the Grand Canyon: Water Resources Research, v. 32, p. 1375-1386.

Wolman, M.G., 1954, A method of sampling coarseriver-bed material: Transactions of the American Geophysical Union, v. 35, no. 6, p. 951-956. 